ISSN: 0213-2060

DOI: http://dx.doi.org/10.14201/shhme201432239270

\title{
ORDENANZAS SEÑORIALES Y VIDA COTIDIANA EN EL COMIENZO DE LA EDAD MODERNA SEGOVIANA ${ }^{1}$
}

\author{
By-laws in the Feudal States and Daily Life in the Beginning \\ of the Modern Age in Segovia
}

José Miguel LÓPEZ VILLALBA

Depto. de Historia Medieval y Ciencias y Técnicas Historiográficas. Facultad de Geografía e Historia. Universidad Nacional de Educación a Distancia. C/ Senda del Rey, s/n. E-28040 MADRID. C. e.: jlopez@ geo.uned.es

Recibido: 2013-04-18

Revisado: 2013-07-06

Aceptado: 2013-09-20

BIBLID [0213-2060(2014)32;239-270]

RESUMEN: Los concejos medievales contaron desde los primeros tiempos de su constitución con una serie de disposiciones en las que apoyarse para preservar sus intereses. En los últimos tiempos de la Edad Media el aumento de la autonomía concejil fue cercenado en las villas que pertenecían a señoríos nobiliarios, porque desarrollaban una gestión acorde a los beneficios del aristócrata. El estudio de las ordenanzas seńoriales de la comunidad de Fuentidueña, emitidas a mediados del siglo XVI, permite conocer en su variada temática las resistencias habidas entre la población a cumplimientos referentes al ocio obligado, el trabajo o el abastecimiento y las consecuentes prohibiciones y condenas.

Palabras clave: Baja Edad Media. Alta Edad Moderna. Ordenanzas municipales. Concejos. Señoríos. Caza. Pesca. Fiestas. Bodas. Vino.

1 El presente trabajo ha sido realizado en el marco del proyecto de investigación $\mathrm{I}+\mathrm{D}+\mathrm{i}$, financiado por el Ministerio de Economía y Competitividad (referencia HAR2012-32298), titulado: «Escritura y ciudad en la Corona de Castilla (siglos XIII-XVIII)». 


\begin{abstract}
The medieval councils had from their origins a number of regulations in order to preserve their interests. In the Low Middle Ages the self-government of the town councils was lessen in those villages which belonged to feudal states, as they worked in the interests of the aristocrats. The study of the by-laws in Fuentidueña, issued at the mid-sixteenth century, allows us to know through different issues the opposition of the population to obey some rules related to the forced leasure, work, supplies to the villages and, as a result, the bans and sentences.
\end{abstract}

Keywords: Late Middle Ages. High Modern Age. By-laws. Town Council. Feudal States. Hunting. Fishing. Public Festivities. Wedding. Wine.

SUMARIO: 0 Introducción. 1 El señorío de Fuentidueña durante los siglos XIIIXVI. 2 Señores y ordenanzas municipales: el concejo en sus manos. 3 Las ordenanzas de Fuentidueña de 1543. 3.1 Las fiestas religiosas: asistencia popular y obligación normativa. 3.2 La celebración de las bodas y la desigualdad social. 3.3 La regulación de los juegos de azar. 3.4 La caza y la pesca: ¿diversión o subsistencia? 3.5 El vino: negocio y placer. 4 Conclusión. 5 Apéndice documental.

\title{
0 INTRODUCCIÓN
}

El fortalecimiento del avance territorial en los reinos de Castilla y León durante la reconquista cristiana se basó en buena medida en la consolidación de los poblamientos civiles situados en las zonas fronterizas. Cada uno de estos asentamientos se cimentó tras la obtención de un contrato tradicionalmente otorgado por el rey. En dichos documentos se contenían las ventajas que encontraban los nuevos pobladores al trasladarse a dichos lugares que, en algunas ocasiones, no se hallaban debidamente consolidados. Por medio de las cartas pueblas y los fueros concejiles, que se fueron implantando con rapidez y llegaron a formar al menos cuatro grandes familias normativas ${ }^{2}$, aquellos territorios quedaron en su mayor parte bajo el dominio realengo, aunque gozando de una serie de ventajas particulares que les permitían cierto desarrollo autonómico ${ }^{3}$.

La corona de Castilla fue variando en el entendimiento de la distribución territorial y presentaba un espacio repartido en señoríos, sobre todo en los siglos XIV a XVI, como resultado de una compleja política ${ }^{4}$. Los señores de haciendas y vasallos llegaron a poseer

2 Es conveniente acudir a la obra clásica de Alfonso García-Gallo de Diego y a uno de sus artículos emblemáticos: «Aportación al estudio de los Fueros». Anuario de Historia del Derecho Español, 1956, vol. 26, pp. 387-446. Recientemente este autor ha tenido una interesante revisión en profundidad de su obra sobre los fueros: Porras Arboledas, Pedro. "Los fueros medievales dentro de la producción de Alfonso García-Gallo». Cuadernos de Historia del Derecho, 2011, vol. 18, pp. 115-162.

3 Barrero García, Ana M. a y Alonso Martín, M. ${ }^{a}$ Luz. Textos de Derecho Local español en la Edad Media. Catálogo de fueros y costums municipales. Madrid: CSIC, 1989.

4 Rubio PéRez, Laureano Manuel. «Fueros concejiles y régimen señorial en el reino de León. Instrumento foral, conflictos y proceso de territorialización de una renta feudal, siglos Xv-XIX». Chronica Nova, 2005, vol. 31, pp. 427-470. 
un patrimonio de desigual consideración y ostentaron, siguiendo los postulados del maestro Salvador de Moxó, los dos elementos que hacían posible la definición de señorío pleno: el solariego y el jurisdiccional ${ }^{5}$. La naturaleza de este estudio se centrará en la capacidad legislativa de los miembros de la llamada nobleza media, y de cómo controlaban algunos aspectos de la vida cotidiana en los concejos pertenecientes a sus señoríos a través de la normativa emanada en sus escribanías. Dicha recreación de la normalización urbana se ejemplificará en el señorío de Fuentidueña, en la actual provincia de Segovia.

El crecimiento desmedido que alcanzaron los seńoríos durante los siglos XIV a XVI, sobre todo en el aspecto jurisdiccional, favoreció que los señores ejerciesen una labor de dominio aristocrático cada vez más intensa y, por ende, más contraria a los intereses de los dominados. Así se generó un espacio fragmentado en múltiples centros de poder dentro del reino. Dichas entidades, independientes y complejas, necesitaban gestionarse por medio de administradores, oficiales y siervos de todo nivel que cubriesen las funciones que se habían trasplantado desde un hipotético estado central a sus sedes señoriales ${ }^{6}$. Un procedimiento que cubría todas las situaciones y gastos posibles de cualquier Corte, y que asimismo se hacía más complicado con el tiempo, era natural que conllevase considerables gastos ${ }^{7}$. Los dispendios necesitaban cubrirse con ingresos continuos y estos

5 Salvador de Moxó fue el estudioso que dio un fuerte impulso a los estudios sobre los señoríos. Moxó, Salvador de. «Los señoríos: cuestiones metodológicas que plantea su estudio». Anuario de Historia del Derecho Español, 1973, vol. 43, pp. 271-310; «Los señoríos: estudio metodológico». En Actas de las I Jornadas de metodología aplicada de las ciencias históricas. Santiago de Compostela: Secretariado de Publicaciones de la Universidad, 1975, vol. II, pp. 163-174; «El señorío, legado medieval». Cuadernos de Historia, 1967, vol. 1, pp. 105-118; «Los seńoríos. En torno a una problemática para el estudio del régimen señorial». Hispania. Revista Española de Historia, 1964, vol. 94-95, pp. 185-236 y 399-430; «La nobleza castellano-leonesa en la Edad Media. Problemática que suscita su estudio en el marco de una historia social». Hispania. Revista Española de Historia, 1970, vol. 114, pp. 5-68. Recientemente se publicó un compendio de sus obras en: Feudalismo, señorio y nobleza en la Castilla medieval. Madrid: Real Academia de la Historia, 2000.

6 Durante tres décadas el profesor Alfonso Franco se ha dedicado al estudio de casos particulares de señoríos repartidos geográficamente que resultaría ocioso reproducir, aunque dejaremos constancia de un par de títulos: Franco Silva, Alfonso. «La implantación de señoríos laicos en tierras de Toledo durante el siglo XV. El ejemplo de Gálvez». En I Congreso de Historia de Castilla La Mancha. Vol. 6, Tomo I, Campesinos y señores en los siglos XIV y XV. Toledo: Junta de Comunidades de Castilla-La Mancha, 1988, pp. 65-73; y con BeCeiro PItA, Isabel. «Tábara: un largo y complejo proceso de formación señorial en tierras de Zamora». Anales de la Universidad de Alicante. Historia Medieval, 1986, vol. 4-5, pp. 201-224.

7 Existe una multitud de estudios de gran calado sobre la cuestión de los señoríos, tanto desde la vertiente general como particularizados en poblaciones y comunidades. Recientemente se han realizado dos trabajos colectivos, uno: Revista de Historia Moderna. Anales de la Universidad de Alicante, 2006, vol. 24 (dedicado a: Señores y señorios: aspectos sociales y económicos); y el segundo: Los señoríos en la Andalucía Moderna. El Marquesado de los Vélez (coord. por Francisco Andújar Castillo y Julián Pablo Díaz López). Almería: Instituto de Estudios Almerienses, 2007. Por otro lado se destacarán algunos de los que han supuesto un aporte firme para un análisis variado de la cuestión: Beceiro PitA, Isabel. «Los estados señoriales como estructura de poder en la Castilla del siglo XV». En RucQuoI, Adeline (coord.). Realidad e imágenes del poder en España a fines de la Edad Media. Valladolid: Ámbito Ediciones, 1988, pp. 293-324; Diago Hernando, Máximo. Estructuras de poder en Soria a fines de la Edad Media. Valladolid: Junta de Castilla y León, 1993; Ladero Quesada, Miguel Á. «Los señoríos medievales onubenses: periodo de formación». En Carriazo Rubio, Juan Luis y Miura Andrades, José María (coords.). Huelva en la Edad Media: reflexiones, aportaciones y nuevas perspectivas veinte años después. Huelva: Universidad de Huelva, 1998, pp. 203-228; Monsalvo Antón, José M.a. El sistema político concejil. El ejemplo del señorío medieval de Alba de Tormes y su concejo de Villa y Tierra. Salamanca: 
provenían de las dos fuentes habituales: tierra y personas. Es decir, que las heredades y los vasallos resultaron pozos sin fondo donde se obtenían los recursos que permitieron el tránsito del seńorío como instrumento puramente nominal al ejercicio de dominio de un territorio geográfico junto con su población. Fue en el conjunto de villas y aldeas diseminadas por los territorios castellanos donde se gestó el crecimiento de las oligarquías terratenientes de la modernidad.

En definitiva, desde el siglo xIv se observa el crecimiento de una nobleza nueva surgida de los continuos enfrentamientos regios y las consecuentes consolidaciones de conjuntos familiares dentro de los grupos privilegiados ${ }^{8}$. Las llamadas «mercedes enriqueñas», ejemplo de privilegios y dispensas repartidas sin descanso por Enrique II, fueron el comienzo de una política entreguista que practicaron por igual los sucesivos reyes trastámaras, sobre todo Juan II y su hijo Enrique IV. Las crisis sucesivas azotaron la estabilidad presupuestaria del reino, pero, contrariamente a lo presumible, la generosidad de los reyes continuó favoreciendo la consolidación de la nobleza que se afianzó en los estratos más elevados de la pirámide social. Desde este contexto, durante el reinado de Juan II se produjeron situaciones agitadas entre los grupos de nobles con linajes establecidos y las figuras emergentes de los favoritos reales. Los grandes protagonistas fueron Álvaro de Luna ${ }^{9}$ o Juan Pacheco ${ }^{10}$, que llegaron a convulsionar el reino por medio del enfrentamiento de sus respectivos grupos de nobles clientelares. Aquellas pugnas, que ocuparon buena parte del siglo Xv, ocupando el reinado de Enrique IV y el comienzo del de Isabel I, propiciaron, entre otras circunstancias, el asentamiento de un nuevo régimen de gobierno. De tal suerte que los Reyes Católicos, aunque siempre estuvieron abiertos al pacto provechoso por medio del diálogo, desarrollaron una fuerte tendencia al control completo del reino ${ }^{11}$.

Universidad de Salamanca, 1988; Moxó, «La nobleza castellano-leonesa en la Edad Media», pp. 7-27. PASTOR, Reyna. «Reflexiones sobre los comienzos de la formación política feudo-vasallática en Castilla y León». En RuCQuOI, Realidad e imágenes del poder, pp. 11-22.

8 Un resumen de la bibliografía reciente acerca de la nobleza del siglo xv: OrTega Cervigón, José Ignacio. «La nobleza peninsular en época trastámara. Principales líneas de investigación (1997-2006)». eHumanista, 2008, vol. 10, pp. 104-132.

9 Todavía hoy resulta admirable la diversidad de visiones que se concentran en las publicaciones sobre esta temática. En lo que se refiere a la figura del privado don Álvaro de Luna nos remitimos a las notas 22, 23 y 24 .

10 La figura del Marqués de Villena resulta tan interesante por la perspectiva de su ascenso político como la manifestada como intrigante. Uno de los estudiosos que se han dedicado al tema, Alfonso Franco, ha publicado en los últimos años varios estudios sobre esta cuestión: Franco Silva, Alfonso. «Las intrigas políticas de Juan Pacheco del combate de Olmedo a la muerte de Juan II (1445-1454)». Anuario de Estudios Medievales, 2007, vol. 37, n. ${ }^{\circ}$ 2, pp. 597-652; y «Juan Pacheco. De doncel del príncipe de Asturias a marqués de Villena (1440-1445)". Anuario de Estudios Medievales, 2009, vol. 39, n. ${ }^{\circ}$ 2, pp. 723-775. Finalmente, el mismo autor, ha presentado una obra que se puede considerar definitiva sobre el personaje: Juan Pacheco, privado de Enrique IV de Castilla. La pasión por la riqueza y el poder. Granada: Universidad de Granada, 2011. Recientemente otros autores han trabajado sobre dicho tema: Marino, Nancy F. Don Juan Pacheco. Wealth and Power in Late Medieval Spain. Tempe: ACMRS, 2006.

${ }_{11}$ Entre las disposiciones emanadas de la corte para devolver a la propiedad real dichas franquicias, son destacables las llevadas a cabo en 1480, para conseguir la reducción de juros; o las conocidas como leyes de Toro, aprobadas tras el fallecimiento de Isabel I, que destacan el propósito de regulación de la fundación de los mayorazgos. Nolasco de Llano, Pedro. Compendio a los Comentarios extendidos por el maestro Antonio Gómez a las ochenta y tres leyes de Toro. Valladolid: Lex Nova, 1981, ed. facs., p. 109 (Ley XL) y p. 237 (Ley XLVI). 
JOSÉ MIGUEL LÓPEZ VILLALBA

ORDENANZAS SEÑORIALES Y VIDA COTIDIANA

EN EL COMIENZO DE LA EDAD MODERNA SEGOVIANA

En cualquier caso, la política castellana de Isabel no fue abiertamente antiseñorial y los grandes poseedores pudieron disfrutar durante dicho mandato de grandes beneficios motivados, tal como apuntaría la propia reina en su testamento, "por necesidades e importunidades ${ }^{12}$. El desenlace del reinado católico no supuso el fin de las normas, ni de las formas ${ }^{13}$. Demasiados intereses para acabar súbitamente, por ello se puede observar cómo continuaron algunos de los aspectos medievales durante un tiempo largo dentro de la Edad Moderna ${ }^{14}$.

\section{El SEÑorío de FuentidueÑa DURANTE LOS SIGLOS XIII-XVI}

La Comunidad de Villa y Tierra de Fuentidueña, sustento del señorío de idéntico nombre, se encuentra situada en la zona occidental de la actual provincia de Segovia. Presenta un paisaje muy variado con varios cursos de agua entre los que destaca el Duratón, afluente del Duero, que la atraviesa de este a oeste, dividiéndola en dos mitades casi iguales, para abandonarla después justo antes de su desembocadura en el Duero a la altura de Peńafiel. El resto de la red hidrográfica no es significativa y se limita a un conjunto de riachuelos subsidiarios del citado Duratón, como el arroyo de la Hoz, el arroyo de las Bragadas o el arroyo de la Vega, llamado igualmente de Sacramenia. La ausencia de una red hídrica con corrientes de gran caudal no se manifiesta en la vegetación al existir por doquier arroyos que se mantienen de las aguas de lluvia. Esto procura una espesura consistente pero estacional, puesto que sin ser una tierra eminentemente seca, llegado el verano sufre un estiaje muy acusado, lo que produce un paisaje formado principalmente por el quejigar propio de un suelo con abundancia en tierras de carácter calizo. Consecuentemente, es de creer que en los siglos medievales y modernos, y conocida la continentalidad del clima, hubiese una gran extensión de encinares en todos estos terrenos que compartirían junto con los pinos resineros el conjunto de la superficie boscosa de la susodicha Comunidad ${ }^{15}$.

El nacimiento administrativo y político de la Comunidad de Villa y Tierra de Fuentidueña no se conoce con certeza aunque, según mantiene Cuéllar Lázaro, existen noticias generadas durante los últimos años del siglo $\mathrm{x}^{16}$. Por otro lado, constan algunas

12 García y García De Castro, Rafael. Virtudes de la Reina Católica. Madrid: Patronato Marcelino Menéndez Pelayo, 1961.

13 Ortega Cervigón, «La nobleza peninsular en época Trastámara», pp. 104-132.

14 Entre la multitud de títulos publicados en los últimos tiempos con motivo del V Centenario de su muerte: VAl Valdivieso, M. ${ }^{a}$ Isabel del y Valdeón Baruque, Julio. Isabel la Católica, reina de Castilla. Valladolid: Ámbito, 2004.

15 Olmos Herguedas, Emilio. Agua, paisaje y ecohistoria. La comarca de Cuéllar a partir del siglo XIII. Valladolid: Universidad de Valladolid, 2011.

16 Recientemente se ha defendido en la Universidad Complutense de Madrid una tesis doctoral, cuyo autor es Juan Cuéllar Lázaro, que lleva por título: Fuentidueña: Comunidad de Villa y Tierra, (Segovia), (siglos $X I I I-X V I I)$. Al no haberse producido hasta este momento la publicación de este trabajo, aunque existe uno anterior (2007), de similar título, las citas que se hagan de dicho trabajo se harán a las páginas de la citada Tesis que se encuentra publicada en la página web de dicha universidad. 
referencias anteriores sobre algunas villas, que con posterioridad se unieron para formar el señorío de Fuentidueña. Con todo, las primeras noticias sobre los orígenes de dicha Comunidad se conocerán a partir de las dataciones de ciertas ofrendas que realizó el rey Alfonso VII al monasterio de Santa María de Sacramenia. Estos diplomas nos ofrecen los primeros datos fiables, puesto que se recoge claramente la expresión Fontedonnae. Alfonso VII, el 20 de junio de 1147, entregó a Santa María de Sacramenia la potestad sobre determinadas tierras para que fuesen de su propiedad y puedan hacer con ellas lo que desearen. En el desarrollo del diploma se sitúa dicho monasterio en el espacio geográfico circundante: "qui est in termino Fontedonnae» ${ }^{17}$. Habrá que esperar medio siglo para que de nuevo encontremos la expresión Fuentedonna referida dentro de una confirmación que realizó Alfonso VIII en 1207 al citado monasterio ${ }^{18}$. Cuatro décadas más tarde, en 1247, aparece la zona enmarcada en un arciprestazgo ${ }^{19}$.

El siglo XIII fue una época de transición en la que la Comunidad conoció el crecimiento, pero igualmente la dificultad. Esta última encajaría con toda seguridad con las graves crisis climáticas y de subsistencia de comienzos del siglo xIV. Durante el mandato de Alfonso XI se fechan las primeras noticias sobre un tal Rui Gil de Castañeda, señor de Fuentidueña. El primer señor conocido se vio inmerso en los trances y disputas que surgieron entre su valedor, don Juan Manuel, y el mencionado rey Alfonso XI. Al final de las dificultades entre los personajes principales del drama, la villa pasará a don Tello, hijo del rey Alfonso. En los años posteriores se sucedieron los nombres de los posesores del señorío, que no dejaron noticias de mayor relevancia, si exceptuamos la referencia al reconocimiento de los privilegios de dicha villa en las cortes de Madrid de $1390^{20}$.

La evolución del señorío se enmarca en una serie de movimientos políticos que estuvieron marcados por la contingencia y determinaron que la posesión del mismo fuese detentada, según las conveniencias del momento, por los reyes o, en su defecto, por ciertos seńores $^{21}$. A mediados del siglo Xv se reemplazó la inestabilidad precedente por un largo periodo en manos de la misma familia, recayendo la propiedad del señorío en un descendiente de don Álvaro de Luna, privado de Juan II $^{22}$. Efectivamente, la designación

17 Es sabido que los autores de los documentos de la alta y plena Edad Media, para situar los lugares menos conocidos, utilizaban la cercanía geográfica a otros sitios más acreditados. Por ello, se ha de entender que para las fechas de este diploma, si se cita referencialmente la villa de Fuentidueña no solo es porque está habitada, sino porque además es alusión administrativa central para situar otros lugares de la zona. CuÉLLAR LÁzAro, Fuentidueña, pp. 492-493.

18 González, Julio. El reino de Castilla en la época de Alfonso VIII. Madrid: CSIC. 1960.

19 Cuéllar Lázaro hace un extenso recorrido a través de los diferentes lugares que componen el "archipresbiteratu de Fuente Duenna», partiendo de las primeras noticias que se conocen de cada uno de ellos y su adscripción a la misma. Cuéllar Lázaro, Fuentidueña, pp. 46-52.

20 Hernansanz Navas, Justo. Fuentidueña y su alfoz. Notas histórico-arqueológicas. Madrid, 1985.

21 Sobre el avance de los seńoríos durante el comienzo de la Baja Edad Media: Álvarez Borge, Ignacio. «Los señoríos en Castilla la Vieja a mediados del siglo xIV». Studia Historica. Historia Medieval, 1996, vol. 14, pp. 181-220. Del mismo autor: «Dependencia campesina, propiedad de los señores y señoríos en Castilla la Vieja en la Baja Edad Media». Historia Agraria, 1999, vol. 19, pp. 9-41.

22 La figura de don Álvaro de Luna, que ha pasado por ser el primer valido regio de la monarquía hispana, ha tenido muchos acercamientos que han logrado que se entienda mejor y que ha servido de 
JOSÉ MIGUEL LÓPEZ VILLALBA

ORDENANZAS SENTORIALES Y VIDA COTIDIANA

EN EL COMIENZO DE LA EDAD MODERNA SEGOVIANA

de Pedro de Luna y Manuel, hijo natural, pero convertido en legítimo, de don Álvaro de Luna y de dońa Margarita Manuel, sucedió en un momento de poder incuestionable por parte del valido real. Dicho nombramiento se llevó a cabo en 1443, en las vísperas de la batalla de Olmedo, cuyo resultado positivo supuso para el privado real el nombramiento de Gran maestre de la Orden de Santiago ${ }^{23}$. Buenos tiempos para Álvaro de Luna y su familia, que favorecieron que el citado Pedro, casado con Elvira de Ayala, se instalase en la villa con todos los requerimientos a su favor. La posterior caída en desgracia y ajusticiamiento de su padre en Valladolid, no impidió que el seńorío siguiese en manos de los señores del linaje Luna ${ }^{24}$. De este modo, de padres a hijos, se fueron sucediendo, sin mayores problemas, de suerte que tras la muerte del primer señor de Fuentidueña, en 1490, le sucedió su hijo don Álvaro de Luna, que falleció en 1519. El tercer señor fue don Pedro de Luna y Bobadilla que, debido a su vida licenciosa, tuvo algunos problemas y aparecen en la documentación los recursos que contra él pusieron algunos vecinos. A su fallecimiento en 1542, le sobrevino su hijo mayor, Álvaro de Luna y Manrique, que dictó las ordenanzas que hoy nos sirven para conocer mejor el mundo reglamentario de la nobleza media rural. Un espacio político representado por algunos señoríos mantenidos por la nobleza media en el periodo de transición entre el bajomedievo que se aleja y una modernidad, que todavía se manifiesta incipiente.

Durante el gobierno de los Austrias algunos de estos señoríos se convertirán en títulos nobiliarios superiores. Así ocurrió en el caso que nos ocupa, cuando el rey Felipe III concedió el condado de Fuentidueña a don Antonio de Luna y Enríquez, a comienzos de 1602, iniciando con ello un camino de pretensiones cortesanas, aunque no llegaron a afianzarse en los grupos de la nobleza principal del reino ${ }^{25}$.

aproximación crítica al personaje. A continuación, y sin ánimo de cercenar una completa colección de análisis de elevada calidad, destacaremos algunos de ellos: CALDERón ORTEGA, José Manuel. Álvaro de Luna: riqueza y poder en la Castilla del siglo XV. Madrid: Dykinson, 1998; Foronda, François. «La privanza dans la Castille du bas Moyen Âge. Cadres conceptuels et stratégies de légitimation d'un lien de proximité». En Alfonso, Isabel; Escalona, Julio y Martin, Georges (dirs.). Lucha politica. Condena y legitimación en la España medieval. Lyon: ENS Éditions, 2004, pp. 153-197; ÍDEM. «Patronazgo, relación de clientela y estructura clientelar. El testimonio del epílogo de la Historia de don Álvaro de Luna». Hispania. Revista Española de Historia, 2010, vol. 70, n. ${ }^{\circ}$ 235, pp. 431-460; Carceller Cerviño, M. a del Pilar. "Álvaro de Luna, Juan Pacheco y Beltrán de la Cueva. Un estudio comparativo del privado regio a fines de la Edad Media». En la España Medieval, 2009, vol. 32, pp. 85-112.

23 Siempre es conveniente el regreso a las clásicas publicaciones sobre las biografías de estos personajes, en este caso de don Álvaro de Luna, que dieron un vuelco en la historia de Castilla y abrieron un camino, que de momento se cerró con los Reyes Católicos. La edición más utilizada ha sido la de Carriazo, Juan de Mata (ed.). Crónica de don Álvaro de Luna, condestable de Castilla, maestre de Santiago. Madrid: Espasa-Calpe, 1940. Recientemente se ha publicado una nueva colección documental que aporta noticias para el discernimiento de la época y del protagonista. Calderón Ortega, José Manuel. Álvaro de Luna (1419-1453). Colección diplomática. Madrid: Dykinson. 1999.

24 La herencia del señorío de Fuentidueńa fue una de las cuestiones menos problemáticas a la hora de la desaparición del valido, cuyas propiedades sufrieron suerte desigual. Franco SiLva, Alfonso. «El destino del patrimonio de don Álvaro de Luna. Problemas y conflictos en la Castilla del siglo xV». Anuario de Estudios Medievales, 1982, vol. 12, pp. 549-584; Í́Dem. El señorío toledano de Montalbán: de don Álvaro de Luna a los Pacheco. Cádiz: Universidad de Cádiz, 1992.

25 Cuéllar Lázaro, Fuentidueña, pp. 63-64. 


\section{SeÑores y ORDENANZAS MUNiCIPALES: EL CONCEJO EN SUS MANOS}

Las instituciones surgen como respuesta a una necesidad social o política. Los concejos altomedievales nacieron ante la necesidad de convivencia de grupos más o menos numerosos de personas. Para ser gobernados surgieron una serie de preceptos legales básicos que con el paso del tiempo evolucionaron desde una forma primitiva de entender el derecho desde la costumbre hasta la complejidad de las ordenanzas locales de la Baja Edad Media. Las ordenanzas fueron la base del derecho local durante casi todo el periodo medieval. La creación de la ordenanza como fuente de dicho derecho local requiere de la existencia de unos elementos esenciales que podemos resumir en tres aspectos. En primer lugar, que sean referidas a un ámbito territorial, reducido al municipio y su alfoz; en segundo que presenten una temática que recoja todos los aspectos más significativos de la vida municipal; y, finalmente, que respondan a una voluntad de pervivencia ${ }^{26}$.

Autonomía, experimentación y evolución desde la alta Edad Media fueron tres propuestas a seguir para la consecución de las futuras normalizaciones jurídicas bajomedievales y modernas. No existió una creación ex novo generalizada, sino que los ensayos se sustentaron en la «consuetudo» particular, que había regido los lugares desde los tiempos remotos y cuyas lecciones habían sido puntal de la praxis cotidiana. Dicha costumbre fue un elemento aglutinador de acciones cotidianas que, enriquecidas por los resultados, terminaron teniendo fuerza de ley ${ }^{27}$.

Las ordenanzas municipales fueron principalmente una acción de gobierno. Por medio de las normas concejiles se matizaron las estrategias del poder urbano y su posterior afianzamiento ${ }^{28}$. Un largo proceso de normalización reglamentaria que procuraba, como fin último, el control de los apartados más relevantes de la economía urbana, entre ellos el abastecimiento. El comercio aparece como principal destinatario de las maniobras políticas de los grupos emergentes que en las urbes situadas en los señoríos estaban plenamente dirigidas por los seńores ${ }^{29}$. El propósito era monopolizar las transacciones económicas y, por ello, en dichas poblaciones el señor y los grupos dominantes comenzaron atribuyéndose unas potestades amplias desde las que hicieron emanar las regulaciones que más les convenían ${ }^{30}$.

Pero igualmente, las ordenanzas resultaron un conjunto de normas que representaban la solución particular para cada uno de los cuantiosos problemas que se suscitaban en la

26 Carrilero Martínez, Ramón. «Diplomática municipal: las ordenanzas. Teoría y práctica». Anales del Centro de la UNED de Albacete, 1987-1989, vol. 9, p. 75.

27 Embid Irujo, Antonio. Ordenanzas y reglamentos municipales en el Derecho español. Madrid: Instituto de Estudios de Administración Local, 1978.

28 Una propuesta novedosa dentro de un estudio comparativo es la resultante del análisis metodológico de Olmos Herguedas, Emilio. «El poder urbano y sus estrategias para influir sobre el territorio. Aproximación metodológica desde las ordenanzas concejiles castellanas». En Arízaga Bolumburu, Beatriz y Solórzano TelecheA, Jesús Ángel. La ciudad medieval y su influencia territorial, Logroño: Instituto de Estudios Riojanos, 2007, pp. 493-517.

${ }_{29}$ Val Valdivieso, M. ${ }^{a}$ Isabel del. «Indicios de la existencia de una clase en formación: el ejemplo de Medina del Campo a fines del siglo Xv». Anales de la Universidad de Alicante. Historia Medieval, 1988-1989, vol. 7, pp. 193-224.

30 Olmos Herguedas, «El poder urbano y sus estrategias», pp. 516-517. 
JOSÉ MIGUEL LÓPEZ VILLALBA

ORDENANZAS SENTORIALES Y VIDA COTIDIANA

EN EL COMIENZO DE LA EDAD MODERNA SEGOVIANA

gestación de nuevos poblamientos, que nacieron señalados por su origen real o señorial ${ }^{31}$. Con posterioridad se generaron diferencias en sus desarrollos políticos, económicos y sociales, de modo que el planteamiento de soluciones generalizadas resultó enormemente complicado $^{32}$. Las normas nacieron como instrucciones de vida y llegaron a ser tan variadas como lo eran las poblaciones a las que estaban destinadas. Los conflictos generados por la superposición de intereses entre las diferentes instituciones reales y seńoriales, junto con los intentos de que prevaleciesen sus propias normativas, originaron a menudo tropiezos en la aplicación de la regla. Las autonomías políticas de las poblaciones enriquecieron el derecho local componiendo una trama, tan interesante como heterogénea, de disposiciones que, al menos a lo largo de los siglos XIII al XVI, dio lugar a un múltiple conjunto de recursos para la aplicación del derecho local.

El deseo que manifestaron los propios municipios de avanzar en la aplicación del derecho local propició una cooperación involuntaria en la promulgación de las medidas reales de Alfonso X, al solicitar la aprobación de nuevas normas que mejorasen su legislación y de este modo asistieron impotentes a los comienzos de la actividad intervencionista regia. Un camino que rendirá un primer destino en la normativa expedida en las cortes de Alcalá de 1348 por Alfonso XI. El cambio llevado a cabo por la citada reforma municipal con la llegada de corregidores y regidores, oficiales muy atados al poder de la Corona, trajo consigo una mudanza de rumbo en el devenir político de los municipios. La reforma propició un intento de pacificación en el gobierno de los concejos por medio de los pactos establecidos entre los diferentes grupos sociales. Una vez solucionadas las tensiones, o al menos suavizadas, como opina Manuel González, los grupos oligárquicos volvieron a la conexión con el poder real, principio de legitimidad más relevante del momento. Los vecinos pecheros pierden su derecho a participar, aunque fuese simbólicamente, en muchas de las actividades comunales de la asamblea municipal. A partir de entonces será un grupo cerrado de regidores el responsable de las actividades municipales que únicamente responderán ante el rey que los había designado o, en su caso, confirmado para el oficio ${ }^{33}$. La intervención regia en el control de los concejos realengos se hacía ostensiblemente manifiesta con el paso del tiempo y se mostró sin fisuras durante el reinado de los Reyes Católicos.

Los seńoríos tuvieron un crecimiento exponencial durante el tardomedievo. Los señores fueron adquiriendo mayores prerrogativas sobre sus dominados por medio de una oficialidad local complaciente con sus deseos, puesto que oportunamente había sido situada en los lugares más estratégicos de los gobiernos concejiles de los señoríos. Estos

31 El término ordenanza se ha venido utilizando para englobar la normativa municipal y una de sus definiciones más certeras es la propuesta por Esteban Corral: «toda norma general, cualquiera que sea su autor, cuyo ámbito territorial se circunscribe al municipio, que se dicta para él y que regula aspectos de la vida económica social, vecinal, de organización y funcionamiento del concejo, su actividad y competencia». Corral García, Esteban. Ordenanzas de los concejos castellanos: formación, contenido y manifestaciones (s. XIIIXVIII). Burgos: s. n., 1988, p. 37.

32 Véase nuestro trabajo: «Los fueros y ordenanzas municipales: embrión de los cabildos coloniales hispanoamericanos». Historia. Instituciones. Documentos, 2006, vol. 33, pp. 339-363.

33 González Jiménez, Manuel. «La creación del derecho local y territorial andaluz. De Alfonso X a los Reyes Católicos». Initium. Revista Catalana d'Història del Dret, 2004, vol. 9, pp. 127-221. 
oficiales eran propuestos por los oligarcas para lograr que su actuación política, cada vez menos ocultada, fuese caracterizada por la impronta del aristócrata dominante en la villa o comunidad. La mejor solución para el señor no pasaba por reprimir cada una de las iniciativas concejiles que aparecían como poco convenientes para sus beneficios, sino en reconstruirlas bajo su dirección. La línea de ejercicio político se dibujó por un amplio colectivo de oficiales y funcionarios pertenecientes, en su mayor parte, a la baja nobleza, como grupo más numeroso de la clase privilegiada. Estos nobles se instalaban en un régimen clientelar y quedaban adscritos a la casa nobiliaria correspondiente. Desde esa situación de dependencia favorecían las pretensiones de los señores en el gobierno local. Uno de los ejemplos más significativos se puede analizar en la ciudad de Guadalajara donde, a lo largo del siglo xv, la familia de los Mendoza actuó como dueña y señora de la ciudad, aunque la misma mantuvo en todo momento la cualidad realenga ${ }^{34}$.

El dilatado abanico de oficiales que desarrollaban su actividad en el manejo del gobierno local puede servir para ejemplificar la complejidad del desarrollo normativo. Llegados a este punto, no es necesario advertir lo verdaderamente enredado que resultaría sistematizar el proceso, más aún, conocida la aplicación que de dicha normativa hacía una pléyade de empleados para gestionar la política de las diferentes poblaciones ${ }^{35}$. Todo aquel sistema estaba encaminado al control total de los pecheros. En primer lugar el diseño de la cuestión político-económica de cada localidad, cuestión verdaderamente esencial para la intervención posterior mucho más pormenorizada, que podía llegar a detalles tan prolijos, como se verá a continuación, como el intervencionismo en los viajes efectuados los domingos y fiestas de guardar por los no privilegiados, algo aparentemente sin mayor trascendencia pero que da una muestra de la injerencia en la vida cotidiana de los sometidos ${ }^{36}$.

En definitiva, los oficiales de los concejos señoriales respondían a unos intereses claramente dirigidos por los grupos privilegiados, transformando las ordenanzas en herramientas a su servicio, con un objetivo final tan variado como lo eran los intereses de los aristócratas que legislaban. La atribución competencial que poseyeron los concejos permitió, en más ocasiones de las que hubiese sido conveniente, que por encima del interés local estuviese el particular. Qué duda cabe que los oficiales locales adjuntos a los señoríos nunca dictaron pautas que contradijesen las normas ordinarias del reino o algunas materias de interés general emanadas desde la Corona ${ }^{37}$.

\section{Las ordenanzas de Fuentidueña de I 543}

Las ordenanzas analizadas se enmarcan dentro de la concepción de dominio señorial que recorre, tal como se ha apuntado, el espacio político castellano desde la Baja Edad

34 LaYna Serrano, Francisco. Historia de Guadalajara y sus Mendoza en los siglos XV y XVI. 4 vols. Madrid: Aldus, 1942 (reed. Guadalajara: AACHE, 1993).

35 López Villalba, José Miguel. «El concejo imparte justicia: cotos de los oficiales locales a mediados del siglo XV». Espacio, Tiempo y Forma. Serie III. Historia Medieval, 2009, vol. 22, pp. 153-184.

36 Ordenanzas de Fuentidueña de 1543 , n. ${ }^{\circ}$ VI.

37 Blasco Díaz, José Luis. Ordenanza municipal y ley. Madrid: Marcial Pons, 2001. 
JOSÉ MIGUEL LÓPEZ VILLALBA

ORDENANZAS SEÑORIALES Y VIDA COTIDIANA

EN EL COMIENZO DE LA EDAD MODERNA SEGOVIANA

Media hasta los siglos de la modernidad. En primer lugar hemos de seńalar que un análisis como este puede parecer poco original por tratarse de unos preceptos que fueron dictados en 1543, es decir, que se emitieron en un momento de asentamiento jurídico municipal en el cual las novedades resultan poco habituales. De este modo, el estudio de unas ordenanzas señoriales redactadas en el primer periodo de la modernidad se encuentra plenamente justificado, porque con ello se puede demostrar que los hechos regulares de la vida cotidiana de la baja Edad Media no sufrieron cambios de un modo rápido, sino que se decantaron con lentitud. En estos años los dictados de reglas locales que se fueron sucediendo en los concejos no resultaron innovadores sino que aparecen como recopilaciones de normativas pasadas. Aunque bien es cierto que se actualizaron algunas cuestiones, en general se correspondían a una realidad anterior ${ }^{38}$.

En definitiva, la vida urbana de la Edad Media no se renovó absolutamente con el cambio de siglo sino que continuó basada en la consolidación de ciertas pautas recogidas en las colecciones medievales. Por otro lado, opinamos que el análisis puntual de una localidad concreta ayudará a la suma de estudios en todas las poblaciones posibles, lo que permitiría en un futuro la mejor reconstrucción de los espacios históricos, matizando algunas respuestas que damos por sabidas.

Dichas ordenanzas emitidas por don Álvaro de Luna, IV señor de la Comunidad de Villa y Tierra de Fuentidueña en Segovia, serán analizadas en cuanto a la intervención señorial dentro de la vida cotidiana de sus sometidos, centrándonos en la preparación de las fiestas, juegos y entretenimientos, y asociando a dicho estudio, el suministro del vino, debido a que dicha bebida ocupó un lugar tradicional en la mesa de todos los grupos sociales y fue compañera en cualquier tipo de diversión. Finalmente, las ordenanzas son transcritas en toda su extensión, a modo de apéndice documental.

\subsection{Las fiestas religiosas: asistencia popular y obligación normativa}

La fiesta popular presentó a lo largo del periodo medieval una marcada consideración religiosa debida, sobre todo, a la gran influencia que mantuvo la Iglesia en el amplio contexto de interrelaciones sociales de todo tipo que se desplegaron en este tiempo ${ }^{39}$. Las fiestas religiosas populares que se hacían en las villas y ciudades se canalizaban a través del fervor multitudinario que daba el sentido real a las celebraciones, desbordando el originario significado místico ${ }^{40}$.

38 Un trabajo ejemplificador sobre el trayecto complejo que se produjo en este cambio de época es el realizado por Carmelo Luis en la villa de Piedrahíta. Luis López, Carmelo. La Comunidad de Villa y Tierra de Piedrahita en el tránsito de la Edad Media a la Moderna. Ávila: Diputación Provincial, 1987.

39 Ladero Quesada, Miguel Á. "Medievo festivo». En Benito Ruano, Eloy (coord.). Tópicos y realidades en la Edad Media. Madrid: Real Academia de la Historia, 2002, vol. 3, pp. 69-120.

40 Martín CeA, Juan Carlos. «Fiestas, juegos y diversiones en la sociedad rural castellana a fines de la Edad Media». Edad Media. Revista de Historia, 1998, vol. 1, pp. 111-142. También resulta recomendable la obra colectiva Fiestas, juegos y espectáculos en la España medieval. Actas del VII Curso de Cultura Medieval, celebrado en Aguilar de Campoo (Palencia), del 18 al 21 de septiembre de 1995. Madrid: Polifemo, 1999. 
Los pecheros se movían en un escenario poco apropiado para el disfrute personal o colectivo. Su existencia cotidiana discurría inmersa en el trabajo manual a tiempo completo, y con escasos motivos para el entretenimiento, exceptuando el conseguido dentro del perímetro familiar. Es entendible, pues, que un colectivo desfavorecido por la fortuna, y viviendo una vida poco deseable, buscase en actividades lúdicas de cualquier tipo la posibilidad de esparcimiento. En definitiva, la fiesta se abría ante ellos como un regalo, en muchas ocasiones no gratuito, pero que les servía de distracción y sobre todo los sacaba del pozo por unos días ${ }^{41}$.

Por otro lado, la celebración religiosa acercaba lo incomprensible, lo intangible, al campesino; y de este modo se transforma en un procedimiento de práctica social que ayuda a la intuición de la mística teórica. La asistencia a la fiesta posibilita, aunque no garantiza, la ruptura de los cerrados círculos que albergan a los diferentes grupos sociales. La relación con Dios se generaliza, si bien el desarrollo de la conciencia moral continúa siendo patrimonio de los poderosos. Sentir cercano al Ser supremo, por medio de la participación comunal, no consigue eliminar las contradicciones reales, pero las traslada fuera de la costumbre social devota ${ }^{42}$.

La mayoría de las celebraciones medievales eran de tipo religioso, resultando que cada población tenía las suyas y asumían un carácter fijo en el calendario, dejando las ceremonias civiles para los acontecimientos extraordinarios. En la villa de Fuentidueña las ordenanzas testimonian dos fiestas destacadas: la dedicada a la Virgen María durante el mes de agosto, secundada por la del apóstol Santiago un mes antes ${ }^{43}$. En la meseta castellana eran muy conocidas las festividades de la villa de Medina del Campo que honraba a Santiago apóstol, el 25 de julio; a Santa María, el 15 de agosto; y a San Antolín, el día 2 de septiembre. En la villa de Piedrahíta encontramos gastos recurrentes y abundantes para las fiestas del Corpus Christi, San Juan, Santiago y Nuestra Señora de Agosto $^{44}$. La ciudad de Segovia se muestra más parca en sus manifestaciones y únicamente se celebraban la de San Juan, probablemente la más antigua y de mayor arraigo, y la de Santiago ${ }^{45}$. En la villa condal de Benavente están documentadas las celebraciones de San Juan, Santa María de Agosto y el Corpus Christi ${ }^{46}$.

41 Ladero Quesada, Miguel Á. Las fiestas en la cultura medieval. Barcelona: Areté, 2004.

42 Un ejemplo interesante sobre las fuentes históricas para el conocimiento de la fiesta medieval es el volumen dedicado a Fiestas religiosas y civiles y archivos de la iglesia en la revista Memoria Ecclesiae. De entre los trabajos que contiene destacamos los siguientes: Menéndez Peláez, Jesús. «Fiesta, teatro y liturgia en el teatro medieval y del Siglo de Oro: el testimonio de las constituciones sinodales». Memoria Ecclesiae, 2010, vol. 34, pp. 649-700; y Cantelar RodríGuez, Francisco. «Fiestas y diversiones en los sínodos medievales». Memoria Ecclesiae, 2010, vol. 34, pp. 467-516.

43 Ordenanzas de Fuentidueña de 1543, n. ${ }^{\circ}$ III.

44 López VillaLba, José Miguel. Las finanzas de un consejo castellano: Piedrahita, siglos XV-XVI. Estudio y documentos. Volumen XII (1515-1517). Ávila: Diputación Provincial de Ávila, 2012, pp. 38-45.

45 Asenjo González, María. Segovia, la ciudad y su tierra a fines del Medievo. Segovia: Diputación Provincial de Segovia, 1986, pp. 558-559.

46 Isabel Beceiro nos presenta la participación de las autoridades en la regulación de la fiesta como modelo de intervención seńorial. Beceiro Pita, Isabel. «La intervención de la autoridad en las celebraciones religiosas: las fiestas de Benavente y su tierra (1434-1525)». Edad Media. Revista de Historia, 2009, vol. 10, pp. 199-223. 
JOSÉ MIGUEL LÓPEZ VILLALBA

ORDENANZAS SENTORIALES Y VIDA COTIDIANA

Las clases sociales desfavorecidas apreciaban que la mayoría de las celebraciones piadosas conllevaban el mantenimiento de la cocurrencia popular a los oficios religiosos a costa de la suspensión de sus actividades. La tregua que aportaba la fiesta favorecía su descanso físico, pero acababa perjudicándoles al dejar de percibir los escasos ingresos de sus labores cotidianas. Por ello procuraban soslayar algunas de las obligaciones de los domingos, al igual que del resto de las fiestas devotas. La solución no era fácil. Los concejos pertenecientes a los señoríos, ordinariamente en manos de los grupos más solventes, resolvían los posibles problemas de suntuosidad en la celebración con ordenanzas lesivas para los grupos pecheros. Entre otros aspectos, dichas leyes obligaban, por medio de fuertes multas, a los campesinos y asalariados a que cumpliesen con sus obligaciones religiosas. En la villa de Benavente tales medidas coercitivas guardaron asimismo puntos de contacto con algunas ordenanzas impuestas a los clérigos por sus prelados, con la finalidad de que siguiesen la disciplina eclesiástica y viviesen de manera honesta y ejemplar ${ }^{47}$.

En el caso que analizamos, el señorío de Fuentidueña, llevaba más de un siglo gobernado por el linaje de los señores de Luna, de modo que la organización administrativa territorial y local estaría fuertemente controlada. Los reglamentos hacen alusión a otros anteriores, que infelizmente desconocemos y que con certeza fueron la esencia del desarrollo de la vida cotidiana en dicha comunidad seńorial. En la aludida villa de Fuentidueńa, tanto la fiesta principal de la Virgen María de agosto, como la que se aclamaba en el mes de julio en honor del apóstol Santiago, o cualquier otra celebración de las determinadas por la Iglesia requería unas actividades adaptadas al culto, ulterior procesión y las consabidas colaciones. Asimismo, se imponían unas sanciones indirectas para aquellos que incumpliesen lo prescrito sobre celebración de los cultos. Efectivamente, la celebración multitudinaria de las sobredichas festividades se garantizaba por medio de la persecución a los que realizasen trabajos de cualquier tipo. Una de las primeras prohibiciones estaba orientada a impedir la entrada y salida de la villa con mercancías. Por medio de las ordenanzas estudiadas se negaba taxativamente la posibilidad de aparejar cualquier carreta, con lo que no cabía la oportunidad de hacer ningún porte por cercano que fuese el destino o por escasa que fuese la mercancía a manejar ${ }^{48}$. No se debe olvidar que, a pesar del elevado autoabastecimiento, eran muchos los productos potencialmente necesarios para cubrir las necesidades diarias que se encontraban fuera del alfoz. Al igual que con los carruajes, se vetaba la realización de todo tipo de encargos llamados serviles, es decir, que tuviesen que ver con los trabajos manuales de poca estimación ${ }^{49}$. En cualquier caso, se levantaba la proscripción a partir de la hora de vísperas, con lo cual se daba libertad para reanudar la vida laboral hacia la caída de la tarde. Difícil empeño, si calculamos que la citada hora de vísperas coincidiría con el comienzo de la ausencia de luz.

Por otro lado, la norma reconocía la eventualidad de una escasez urgente de cualquier producto que, debidamente justificada, permitiese el acarreo durante todo el día. La

47 Beceiro Pita, «La intervención de la autoridad». En la misma línea está: PeÑalva Gil, Jesús. «Las iglesias patrimoniales en la Castilla medieval. La iglesia parroquial de San Nicolás de Burgos: institución, ordenanzas y regla de 1408». Anuario de Estudios Medievales, 2008, vol. 38, n. ${ }^{\circ} 1$ pp. 301-366.

48 Ordenanzas de Fuentidueña de 1543, n. ${ }^{\circ}$ IV.

49 Íbidem. 
pena ante la desobediencia era de trescientos maravedís, que se repartían otorgando cien maravedís a la iglesia de la que fuese parroquiano el infractor y los otros doscientos entre el acusador y el juez. Un sistema de reparto tradicional que veremos en la mayoría de las penas impuestas.

Dichas normas, en este caso seńoriales, pero generalizadas en casi todos los concejos castellanos entre finales del siglo XIV y las décadas centrales del XVI, trasladan al plano civil las condenas a los fieles que no santifican las fiestas eclesiásticas. No importaba la necesidad perentoria que mantenía el pueblo de asistir al trabajo. Las persecuciones que desarrollaron los gobiernos locales para garantizar el cumplimiento de las fiestas religiosas estuvieron inspiradas desde los grupos privilegiados. Ciertamente, los seńores laicos y religiosos coaccionaron a los concejos para que emitiesen ordenanzas que ayudasen al mayor boato de las conmemoraciones religiosas, consiguiendo asistencias masivas a las mismas. Dichas penas se endurecieron progresivamente y deben entenderse desde las corrientes reformistas que se desarrollaron en la corona de Castilla, entre el reinado de Juan I y la época inmediatamente anterior al concilio de Trento, con el objetivo de corregir la relajación de costumbres del clero y los fieles ${ }^{50}$.

Otro de los preceptos, prescrito en el mismo orden de cosas, insistía en la necesidad de fiscalizar los viajes particulares los días de obligado cumplimiento, llegando a prohibir la salida de la villa antes de que se celebrase la misa mayor de la fiesta patronal o de los demás días de guardar ${ }^{51}$. Los doscientos maravedís de multa se repartían en tres partes, una de las cuales se aplicaría en la fábrica de la iglesia donde fuese parroquiano el infractor, las otras dos partes se repartían al uso, entre denunciador y juzgador. En todo caso, un correctivo escasamente justificado por tratarse del control de los desplazamientos, muchas veces de naturaleza personal, que bien podrían resultar ineludibles.

La ausencia de libros de mayordomía dificulta el conocimiento de las cuantías empleadas para lograr la mayor solemnidad de dichas conmemoraciones. Con todo, no deja de ponerse de manifiesto el papel del señor como creador del universo de ocio en la villa y aldeas de la Comunidad, a la vez que como fiscalizador del mismo.

\subsection{La celebración de las bodas y la desigualdad social}

Los esponsales han sido a lo largo de la historia uno de los grandes sucesos solemnes correspondientes al círculo familiar. La importancia de la ceremonia nupcial en sí misma, el negocio realizado con el enlace y la garantía de la continuidad de la progenie transformaron los matrimonios en un gran acontecimiento social, que además servía para mostrar el bienestar económico de las familias de los contrayentes ${ }^{52}$.

De nobles a campesinos, todos hijos de Dios, y todos imitadores del fasto de la monarquía para evidenciar su prestigio. En una estructura piramidal como la que cimentaba

50 Beceiro Pita, «La intervención de la autoridad».

51 Ordenanzas de Fuentidueña de 1543 , n. ${ }^{\circ}$ VI.

52 Martínez Carrillo, M. ${ }^{a}$ de los Llanos. «Elitismo y participación popular en las fiestas medievales». Miscelánea Medieval Murciana, 1993-1994, vol. 18, pp. 95-108. 
JOSÉ MIGUEL LÓPEZ VILLALBA

ORDENANZAS SENTORIALES Y VIDA COTIDIANA

EN EL COMIENZO DE LA EDAD MODERNA SEGOVIANA

aquella sociedad, los arquetipos presentados por los grupos privilegiados pronto se quisieron imitar en el mundo de los desfavorecidos por la fortuna, claro está que dentro de las limitaciones que imponía su escaso patrimonio familiar. Las sucesivas leyes suntuarias dictadas desde el siglo XIII persiguieron la lucha contra el lujo excesivo que se había instalado en la sociedad privilegiada a raíz del control del estrecho de Gibraltar. La seguridad en la mar abrió la posibilidad de llegada de numerosos objetos de importación como símbolo de riqueza y ostentación. En tiempos de Alfonso X, las cortes de Valladolid de $1258^{53}$ y las posteriores de Jerez de la Frontera de $1268^{54}$ trataron sobre esta cuestión. Estas normativas propiciaron la creación de dos espacios sociales marcados por la pertenencia a los diferentes círculos económicos y sociales, que se presentaban bien diferenciados en el entendimiento del lujo y la diversión, y que generalmente estaban asociados a un determinado grado de poder político. Los poderes nobiliarios, ante la emergencia de ciertos grupos burgueses y campesinos hacendados impulsaron una política complementaria a las leyes suntuarias del reino para recortar sus fiestas y celebraciones. De este modo los casamientos del colectivo pechero quedaban reducidos en su boato, lo que permitía mantener la distancia social. La obligación de conservar la contención en el gasto se hizo más patente en los estratos más bajos de la escala social ${ }^{55}$.

En esa línea, el señor de Fuentidueña dictó una ordenanza para regular la vigilancia de las invitaciones a los festejos nupciales con el objetivo aparente de evitar dańos durante las celebraciones de las bodas, pero con toda seguridad buscando la reducción del gasto y evitar la complacencia de los pecheros en la imitación de los cortejos y celebraciones de la clase social más elevada. Álvaro de Luna y Manrique se presenta ante nosotros como un noble del momento, pues sus disposiciones dirigidas a los pecheros son similares a las que propuso el II duque de Alba unos años antes para el territorio de su cercano señorío ${ }^{56}$. La rigidez se manifiesta en la redacción de ambas normativas nupciales, aunque una y otra abren la posibilidad de dar una comida con todos aquellos convidados de los contrayentes que sus familias desearan. Desde la cúspide de aquella sociedad compartimentada se cercenaron hasta las posibilidades más inocentes de disfrute de los vasallos ${ }^{57}$. Tal vez porque

53 Cortes de Valladolid celebradas en la Era 1296 (año 1258) por Alonso Décimo llamado el Sabio. Madrid, 1836.

54 Sobre las cortes de Jerez de la Frontera de 1268, Valdeón Baruque, Julio. "Alfonso X y las Cortes de Castilla». En Rodríguez Llopis, Miguel (coord.). Alfonso X. Aportaciones de un rey castellano a la construcción de Europa. Murcia: Editora Regional de Murcia, 1997, pp. 55-70.

55 La persecución a las celebraciones campesinas fue general en toda Europa. Blickle, Peter. «Es evidente perjuicio del bien común: las bodas campesinas en la Edad Media». En Schultz, Uwe (coord.). La fiesta: una historia cultural desde la Antigüedad hasta nuestros dias. Madrid: Alianza Editorial, 1993, pp. $115-132$.

56 Martín Cea, «Fiestas, juegos y diversiones», p. 121.

57 El profesor Riera Melis ha realizado dos estudios comparativos de los productos alimenticios en ambos estamentos sociales que sirven de referencia para el mundo de la corona de Aragón: Riera Melis, Antonio. "Jerarquía social y desigualdad alimentaria en el Mediterráneo noroccidental en la Baja Edad Media: la cocina y la mesa en los estamentos populares». Anuario de Estudios Medievales, 1994, vol. 24, pp. 857-886; y "Jerarquía social y desigualdad alimentaria en el Mediterráneo noroccidental en la Baja Edad Media: la cocina y la mesa en los estamentos privilegiados». Acta Historica et Archaeologica Mediaevalia, 1995-1996, vol. 16-17, pp. 181-205. 
JOSÉ MIGUEL LÓPEZ VILLALBA

ORDENANZAS SEÑORIALES Y VIDA COTIDIANA

EN EL COMIENZO DE LA EDAD MODERNA SEGOVIANA

a los privilegiados no les parecían tan inocuas y veían que por medio de esta representación teatral podían aparentar lo que no eran. Es decir, que se abría una puerta hacia un camino sin retorno, el de la imagen equívoca. En definitiva, con estas celebraciones cualquiera podía fingir ser algo distinto, y eso, en un ámbito marcado por los ideales caballerescos y las escalas feudales, era complicado de entender y, por lo tanto, de permitir.

Siguiendo la ordenanza de regulación nupcial de Fuentidueña se observa cómo una vez que se había producido la comida principal continuaban los agasajos, pero debidamente controlados para que no se excediesen en el número de invitados, de modo que los dejaban reducidos a los parientes de los novios que viviesen en el lugar donde se celebre la ceremonia. Igualmente se ponía la condición de que los anfitriones que respondiesen de la invitación debían ser el desposado o su padre, o bien aquella persona que corriese con los gastos de la boda ${ }^{58}$. La sanción para los que incumpliesen estas normas era ciertamente severa, puesto que alcanzaba la cifra de seiscientos maravedís. Asimismo, el invitado que se quedase a comer o cenar durante los siguientes días, y no estuviese entre los elegidos, debería pagar por cada vez doscientos maravedís ${ }^{59}$. Las ordenanzas de la adyacente villa de Cuéllar, que sirven de referencia obligada por la proximidad geográfica y el tiempo de emisión, son mucho más extensas en el contenido y hacen alusión a numerosas particularidades de los enlaces, haciendo hincapié incluso en la cuestión de los regalos. Por lo que se refiere a las penas son ostensiblemente menores a las de Fuentidueña, fijándose como pauta la cantidad de cien maravedís ${ }^{60}$.

En pocas palabras, los matrimonios se transformaron en una maniobra política en la que los casamientos entre miembros de los grupos privilegiados les llevaron a efectuar banquetes, tan lujosos como abundantes ${ }^{61}$. Durante la celebración de los mismos el derroche alimenticio les hacía consumir ingentes cantidades de carne, cereales y vino. Los señores conseguían préstidos entre sus vasallos para acometer los gastos de los convites posteriores a la ceremonia. Es decir, que los pecheros pagaban lujos de los que no disfrutaban, o al menos no del todo, porque en dichos banquetes había diferentes tipos de invitados y de menú, siendo más liviano el dedicado a los campesinos que acudían a los mismos ${ }^{62}$.

\subsection{La regulación de los juegos de azar}

El juego, entendido como diversión popular en la que se podía mejorar la hacienda con la ganancia de algunos maravedís, se extendió por todos los reinos peninsulares a lo largo de la Edad Media. Los juegos favoritos, en este reconocido vicio nacional, fueron dos: los dados y los naipes. El juego de los dados fue uno de los recreos que con mayor

\footnotetext{
Ordenanzas de Fuentidueña de 1543, n. ${ }^{\circ}$ XXII.

Ibidem.

Olmos Herguedas, Agua, paisaje y ecohistoria, pp. 263-264.

61 Lora Serrano, Gloria. «Estrategia matrimonial y fiscalidad señorial: las bodas de Isabel de Estúñiga y Fadrique Álvarez de Toledo». Historia. Instituciones. Documentos, 2002, vol. 29, pp. 187-215.

62 Ibidem, p. 207.
} 
JOSÉ MIGUEL LÓPEZ VILLALBA

ORDENANZAS SEÑORIALES Y VIDA COTIDIANA

EN EL COMIENZO DE LA EDAD MODERNA SEGOVIANA

asiduidad se practicó en la edad media hispana. Pero no fue un invento ni castellano, ni aragonés, ni medieval, sino de origen oriental ${ }^{63}$. Importado en el occidente europeo, Alfonso X ya lo recoge en las páginas de su extenso Libro de los Juegos ${ }^{64}$. El recreo de los dados no tuvo la finalidad lúdica, que acompañó al juego del ajedrez, sino propiamente lucrativa. De hecho era un esparcimiento que se acompañaba frecuentemente de sustanciosas ganancias o graves pérdidas económicas entre los jugadores, lo que conllevaba a numerosos enfrentamientos con resultado de heridos, cuando no de muertos, y casi siempre acompańados de disturbios, lo cual enrarecía el ambiente urbano ${ }^{65}$.

Otro de los pasatiempos más populares fue el de los naipes. Un solaz con un origen poco claro y con una llegada tardía a los reinos hispanos ${ }^{66}$. Lo cual no fue óbice para que desde finales del siglo XIV se encuentren numerosas referencias negativas sobre el juego y la fabricación de las cartas ${ }^{67}$. Todo un universo de pícaros se aprovechaba de la candidez de aquellos incautos que se acercaban al juego con grandes expectativas, pero que generalmente salían desplumados. Tan extendida estaba la práctica de este vicio como el deseo implícito de mejorar la hacienda por medio de un golpe de fortuna, aunque fuese efímeramente. Estas diversiones por medio de las cartas tuvieron variantes que llegaron hasta las prácticas de adivinación. Los garantes en la pureza de la fe persiguieron esta desviación perversa que convertía los naipes en medios de revelación. El Santo Oficio redactó numerosos informes que contenían recomendaciones para acabar con estas pericias poco convencionales ${ }^{68}$.

Dichas medidas acabaron reflejándose en la mayoría de las reglas concejiles. De este modo vemos cómo en la normativa de Fuentidueña de 1543, se distinguen dos tipos de prohibición manifiesta referida a la práctica del juego: una señalada para los días de fiesta religiosa y otra, más amplia, de tipo general. Al igual que en otras poblaciones, Álvaro de Luna, IV señor de Fuentidueña, prohibió expresamente que se jugase ningún domingo, ni el resto de los días señalados en las disposiciones sobre festividades

63 Los helenos atribuían tal invención a Palamedes de Argos, un héroe de la guerra de Troya. Higino, Cayo Julio. Fábulas mitológicas. Madrid: Alianza Editorial, 2009; Molina Molina, Ángel Luis. «El juego de dados en la Edad Media». Murgetana, 1999, vol. 100, pp. 95-104.

64 Conocido igualmente como Libro del ajedrez, dados y tablas, fue un encargo del rey sabio en su intento de recoger toda la cultura, de cualquier tipo, existente en el reino. Su contenido se extiende en el conocimiento del ajedrez, pero incluye el tratamiento de juegos ciertamente menos edificantes. Raúl Orellana ha publicado recientemente una edición comentada sobre este extraordinario volumen: Alfonso X. Libro de los juegos: acedrex, dados e tablas. Ordenamiento de las Tafurerías (ed. Raúl Orellana Calderón). Madrid: Fundación José Antonio de Castro. 2007.

65 Molina Molina, Ángel Luis. «Los juegos de mesa en la Edad Media». Miscelánea Medieval Murciana, 1997-1998, vol. 21-22, pp. 215-238.

66 Rodrigo Estevan, M. ${ }^{a}$ Luz. "Lo lúdico y lo festivo en el Aragón medieval. Fuentes documentales para su estudio". Aragón en la Edad Media, 2008, vol. 20, pp. 661-676.

${ }_{67}$ Un buen recorrido general por los naipes, su fabricación y sus consecuencias delictivas se puede seguir en Luján, Néstor. La vida cotidiana en el Siglo de Oro español. Barcelona: Planeta, 1988; y PÉrez García, Pablo. La comparsa de los malhechores: Valencia 1479-1518. València: Diputació de València, 1990.

68 «A este Sancto Officio se an traído unos naipes hechos en aquellas partes de marca grande en que ay figuras del papa y otra de una mujer con las mismas insignias del papa. Paresçe manera de yrrisión de Nuestra Religión Christiana...». Citado por Étienvre, Jean-Pierre. Márgenes literarios del juego. Una poética del naipe. Siglos XVI-XVIII. Madrid, 1990, p. 299. Citado por Molina Molina, «Los juegos de mesa», p. 234. 
JOSÉ MIGUEL LÓPEZ VILLALBA

ORDENANZAS SEÑORIALES Y VIDA COTIDIANA

EN EL COMIENZO DE LA EDAD MODERNA SEGOVIANA

religiosas. El veto se extendía únicamente hasta la hora de misa mayor. La pena por el incumplimiento ascendía a trescientos maravedís, que se repartían otorgando un tercio para la iglesia de donde fueren parroquianos los infractores y los otros dos tercios entre el denunciante y la justicia ${ }^{69}$.

En otro apartado normalizador se hace una nueva alusión a los juegos, en esta ocasión centrándose en el lugar donde se ejercitaban, las tabernas ${ }^{70}$. Así, pues, el señor de Fuentidueña ordenó que: «ninguno sea osado de jugar nynguna manera de juego» ${ }^{71}$.

El alegato se basa en las consecuencias negativas que presenta dicha actuación dentro de un espacio donde el vino tiene su mejor santuario, la taberna. Alcohol, dinero y naipes, una mezcla explosiva que podía llevar, tal como dice la propia norma, a que se siguiesen: "muchos dańos e inconbenientes y enojos, muertes y heridas» ${ }^{72}$.

Generalmente el juego tenía sus propios templos, los llamados garitos, pero igualmente se practicaba en las tabernas, como acabamos de ver, en los burdeles, en la calle y hasta en las iglesias, en las horas perdidas para el culto. Del mismo modo se podía recrear en lugares tan peregrinos como los pinares. Efectivamente, en la villa de Cuéllar, en las ordenanzas de 1546, se prohibía a los mozos pinariegos el juego de naipes en los trayectos hacia el pinar a recoger leña, el tiempo en que estuviesen allí o en el camino de regreso $^{73}$.

Por otro lado, se observa que en la redacción de la norma se utiliza la expresión «ninguno», sin ańadir vecinos o moradores. Los naipes no eran un entretenimiento que diferenciase a los grupos sociales, porque pecheros y seńores se entregaban al juego de la baraja con tanto empeńo como el que ponían las autoridades en impedirlo. Tal vez por ello la pena se extiende también a los que estuviesen de paso por la tierra del señorío. Curiosamente a la hora de castigar tal actividad la cantidad no se antoja excesiva, porque la infracción apenas alcanzaba los trescientos maravedís, un tercio para la cámara y los otros dos, como era acostumbrado, prorrateados entre el que puso la denuncia y el juez que lo castigó ${ }^{74}$. Aunque puede resultar elevada si la comparamos con la que castigaba hechos similares en la Comunidad de Villa y Tierra de Cuéllar, en que apenas alcanzaba los cien maravedís ${ }^{75}$.

\subsection{La caza y la pesca: ¿diversión o subsistencia?}

La caza es una actividad que presenta lejanos antecedentes durante los cuales se podía practicar sin cortapisas. Será en el siglo viI cuando aparece la noción de guardabosques («silvarum custos») y con ella una cierta protección de los animales que habitaban en ellos.

Ordenanzas de Fuentidueña de 1543, n. ${ }^{\circ}$ III.

Ibidem, n. ${ }^{\circ}$ VII.

Ibidem.

Ibidem.

73 Olmos Herguedas, Emilio. La Comunidad de Villa y Tierra de Cuéllar a partir de las ordenanzas de 1546. Apuntes para la historia local de Lastras de Cuéllar. Segovia: Diputación de Segovia, 1994, pp. 258-259.

74 Ordenanzas de Fuentidueña de 1543, n. ${ }^{\circ}$ VII.

75 Olmos Herguedas, La Comunidad de Villa y Tierra. 
JOSÉ MIGUEL LÓPEZ VILLALBA

ORDENANZAS SEÑORIALES Y VIDA COTIDIANA

EN EL COMIENZO DE LA EDAD MODERNA SEGOVIANA

Inmediatamente afloran en diferentes reinos los espacios reservados por los monarcas para practicar la cacería. En aquellos tiempos se penaba con la vida a los desobedientes de las normas reales ${ }^{7}$. A partir del siglo $\mathrm{x}$ serán los grandes señores los que adopten esta costumbre que se antojaba selecta. Ya en el siglo XIII aparece en Castilla un manual de caza con el título de El libro de la montería, escrito por el rey Alfonso X, que marcará toda una época de esta actividad ${ }^{77}$.

En la Edad Media se manifiesta como una ocupación que se debate entre el placer y la necesidad ${ }^{78}$. La caza fue tradicionalmente un coto de las clases nobiliarias que se reservaban en sus heredades las mejores piezas para su esparcimiento y entrenamiento físico para la guerra. La caza mayor, que también era conocida como montería, se realizaba con caballos y las piezas a lograr eran cérvidos y jabalíes, quedando los osos reducidos a zonas montañosas muy concretas ${ }^{79}$.

Las ordenanzas de Fuentidueña hablan de ciertas restricciones en la caza y la pesca que debían cumplirse en tiempo de fiestas religiosas. Una corriente de fervor había transformado las fiestas devotas urbanas en un modo de convivencia que en aquellos ańos ya exteriorizaba casi todas las características que lucirá en los siglos posteriores. La propia procesión servía para reflejar el orden social, profundamente jerarquizado, que interesaba mantener. Tal vez por potenciar esa devoción, más o menos forzada, de la que hablamos, lo que planteaban las normas es la prohibición total, para que ninguna persona, fuese vecino, morador u hombre de paso, pudiese llevar a cabo aquellas actividades lúdicas contrarias a la asistencia a las formalidades devotas. Aunque no se especifica manifiestamente, la norma se refiere a la llamada caza menor, tan socorrida para los colectivos pecheros ${ }^{80}$.

Una de las necesidades naturales del ser humano es la alimentación, por ello los grupos pecheros completaban su sustento con lo obtenido en sus actividades marginales en caza menor y pesca artesanal. Labores que acabaron siendo tan habituales que aparecen reglamentadas en prácticamente todos los ordenamientos concejiles ${ }^{81}$. Dicho tipo de caza

76 Le Goff, Jacques y Schmitt, Jean-Claude (eds.). Diccionario razonado del Occidente medieval. Madrid: Akal, 2003, pp. 138-139.

77 Alfonso XI. Libro de la montería (ed. M.a Isabel Montoya Ramírez). Granada: Universidad de Granada, 1992. Recientemente se ha hecho una nueva revisión del mismo: VAlverde, José A. Anotaciones al Libro de la montería del rey Alfonso XI. Salamanca: Universidad de Salamanca, 2009.

78 Para conocer la caza en la Edad Media es referencia inexcusable, a pesar del paso de los ańos: « $L a$ chasse au Moyen Age». Actes du Colloque de Nice (22-24 juin 1979). Nice: Les Belles Letres, 1980. En las actas de este coloquio se publicaron algunos trabajos sobre la caza en los reinos peninsulares.

79 José Manuel Fradejas Rueda ha publicado múltiples análisis y ediciones críticas de libros medievales y modernos sobre el arte de la caza. Se pueden destacar entre sus obras: Bibliotheca cinegética hispánica. Bibliografia critica de los libros de cetrería y montería hispano-portugueses anteriores a 1797. London: Grant \& Cutler, 1991; La literatura cetrera de la Edad Media y el Renacimiento español. London: Queen Mary and Westfield College, 1998. "Libros de caza en los siglos Xvi y XviI: una bibliografía de impresos». Pliegos de Bibliofilia, 1998, vol. 1, pp. 39-45. Igualmente se deben a su coordinación los estudios recogidos en: La caza en la Edad Media. Valladolid: Universidad de Valladolid, 2002.

80 Sobre ordenanzas y caza: Oliva Herrer, Hipólito Rafael. «La caza en el valle del Duero a fines de la Edad Media a través de las ordenanzas municipales». En Fradejas Rueda, José Manuel (coord.). La caza en la Edad Media. Valladolid: Universidad de Valladolid, 2002, pp. 151-165.

${ }_{81}$ Un mejor entendimiento de las actividades cinegéticas y de pesca medievales se puede hacer a través de la literatura, mucha de ella de temática caballeresca, junto con algunas disposiciones de extracción real y 
suscitaba un atractivo mayor para los aludidos grupos por diferentes causas: en primer lugar, eran más sencillas de cazar, además suponían un veloz suplemento pecuniario, por su rápida venta, y, finalmente, eran un complemento en las parcas cazuelas comúnmente alejadas de las proteínas cárnicas.

En cualquier caso, no debemos dejar de lado que, en los momentos de veda o prohibición expresa, el incumplimiento de la norma sobre la aprehensión de presas era más fácil de ocultar ante los encargados de la vigilancia de los montes si se trataba de piezas menudas, es decir, conejos, liebres o perdices, evitando con ello denuncias y castigos. Burlar la ley, como principio capital para lograr sobrevivir, fue norma común en todos los reinos hispanos ${ }^{82}$.

Respecto a las vedas, existieron dos tipos, la territorial y la temporal, que aún siguen vigentes en la actualidad. La territorial era marcada por cada concejo o por el señor, en este caso, de la comunidad de villa y tierra susodicha. Respecto a la veda temporal ya estaba contemplada por la normativa real. El tiempo en que se aplicaba comprendía desde la época previa al Carnaval hasta finales de septiembre, justo hasta el día de San Miguel. Un modelo de prohibición al que se acogió la mayoría de los concejos con competencias sobre esta faceta. En dicha interrupción convendría incluir las paradas biológicas que algunos lugares cercanos al Sistema Central propugnaron durante los tiempos de nieves, tan intensos como largos en el calendario, para evitar la caza indiscriminada de las especies menores, lo cual ayudaba a la reposición de individuos nuevos ${ }^{83}$. Fuera de este régimen quedaba la caza del lobo cuya captura no solo no estaba penalizada, sino que en muchas normativas la encontramos retribuida, puesto que los lobos eran una de las preocupaciones habituales de los caseríos próximos a boscajes profundos. Efectivamente,

bastantes noticias de origen municipal. Entre las primeras destacan: KöHLER, Erich. La aventura caballeresca. Ideal y realidad en la narrativa cortés. Barcelona: Sirmio, 1990; PAstoreAu, Michel. La vida cotidiana de los caballeros de la Tabla Redonda. Madrid: Ediciones Temas de Hoy, 1994; Llul, Ramón. Libro de la Orden de Caballería (ed. José Ramón de Luanco). Barcelona: Teorema, 1985; RiQuer, Martín de. Caballeros andantes españoles. Madrid: Gredos, 2008.

82 Como ejemplos para los diversos reinos hispánicos se pueden citar, para el reino de Mallorca, Cateura Bennasser, Pablo. «La caza en la Mallorca medieval». Bolleti de la Societat Arqueològica Lulliana, 1981, vol. 37, pp. 251-259; y más recientemente: Bover Pujol, Jaume y Roselló, Ramón. "La cetrería en las Islas Baleares. Siglos XiII-XV». En Fradejas Rueda (coord.), La caza en la Edad Media, pp. 9-23. En la corona de Aragón destacan los trabajos de Rodrigo Estevan, M. a Luz. "Cazar y comer caza en el Aragón medieval: fueros, normativas, prácticas y creencias». El Ruejo. Revista de Estudios Históricos y Sociales, 2004, vol. 5, pp. 59-124; y "Hunting and hunters in Medieval Aragonese Legislation». En Prinz, Armin (ed.). Hunting food and drinking wine. Wien: LIT Verlag, 2006, pp. 133-154. Igualmente: «Del Pirineo a la Cordillera Ibérica: Sistemas alimentarios en las montañas de Aragón (siglos XI-XV)». En Food, imaginaries and cultural frontiers. Essays in honour of Helen Macbeth. Guadalajara (México): Universidad de Guadalajara, pp. 405-422. Para el reino de León: García Cañón, Pablo. "La caza en la Montaña noroccidental leonesa en la baja Edad Media». En Fradejas Rueda (coord.), La caza en la Edad Media, pp. 91-98. Finalmente la caza en el reino de Castilla está bien representada en el análisis de Ladero Quesada, Miguel Á. "La caza en la legislación municipal castellana. Siglos XIII-XVIII». En la España medieval, 1980, vol. 1, pp. 193-222.

83 Ladero Quesada mantiene que esta prohibición era casi obligada en tiempo de nieves y se hacía para la protección de animales como conejos, liebres y perdigones, que en ningún caso tenían defensa en esta situación. Hace referencia al Fuero de Cuéllar y a las ordenanzas de Ávila, Cuéllar y Barco de Ávila. LADERo QUESADA, «La caza en la legislación municipal castellana». 
JOSÉ MIGUEL LÓPEZ VILLALBA

ORDENANZAS SENTORIALES Y VIDA COTIDIANA

esos eran los lugares ideales para la reproducción de estos animales y desde allí atacaban en manada a los ganados y personas.

Durante el tiempo de transición entre el medievo y la modernidad se asistió a una política concejil de elevada agresividad contra estos animales considerados dañinos. De facto se puede considerar consolidada la figura del cazador profesional ${ }^{84}$. Como ejemplo valgan los precios pagados en las tierras del seńorío del duque de Alba en los primeros ańos del siglo xvi. En el año 1515, una camada de lobos jóvenes se pagaba a trescientos maravedís ${ }^{85}$.

Aunque en las normas que impuso el IV señor de Fuentidueña se hace alusión a dos tipos de territorio de caza, lo vedado y lo desvedado, la contravención era penada, tal como se ha dicho, por la falta de asistencia a las obligaciones religiosas y no hace mención ni a la época ni al territorio en el que se realiza ${ }^{86}$. Las penas se elevaron a los seiscientos maravedís y son idénticas en ambos casos. Dentro de este conjunto de medidas se añaden otras dos, una referida a la caza menor y otra a la pesca. Respecto a la primera dan noticia a la caza en tiempo vedado y para ello imponen la ley superior o del reino.

La pesca se ha de considerar de valor preferente dentro de la normativa, porque al igual que en otras poblaciones cercanas a cauces fluviales la captura de peces servía para saciar el hambre de los pecheros. Algunos autores sostienen que durante el periodo medieval, e incluso moderno, existió la imagen de una pirámide estructural de prestigio para los alimentos. Esta disposición se veía determinada por un estricto planteamiento mediante el cual determinados valores, reglas y símbolos sociales marcaban los ritmos alimenticios acostumbrados por las familias. Lo mismo se hacía con las minutas de las fiestas solemnes o los empleados en los banquetes ocasionales, sublimando unos productos en detrimento de otros y otorgando, por ejemplo, categoría nutritiva a la carne y negándosela al pescado ${ }^{87}$.

En la Castilla interior era frecuente que la mayor parte del pescado que se ponía sobre las mesas fuese de los ríos colindantes a la población consumidora. Entre las especies sobresalientes se han de destacar la trucha, el barbo, la anguila, y un conjunto de peces sin nombre regularizado, que eran conocidos por diversas denominaciones según las regiones ${ }^{88}$. Algo similar sucedía en el reino de Aragón donde según aumentaba la lejanía al mar se acrecentaba el consumo de la pesca fluvial ${ }^{89}$. Dicha producción no

84 Ser Qujuno, Gregorio del. «Algunas notas sobre la protección animal en Piedrahíta en el siglo XV». En Institución Gran Duque de Alba 1962-2012. 50 años de cultura abulense. Ávila: Diputación Provincial, 2012, vol. II, pp. 331-339.

85 López Villalba, Las finanzas de un concejo castellano, p. 78.

86 Ordenanzas de Fuentidueña de 1543, n. ${ }^{\circ} \mathrm{V}$.

87 Aymard, Maurice. «Pour l'historie de l'alimentation: quelques remarques de méthode». Annales. Économies, Sociétés, Civilisations, 1975, vol. 30, n. ${ }^{\circ}$ 2-3, pp. 431-444. Un reciente y extenso estado de la cuestión sobre alimentación en PÉREz SAMPER, M. ${ }^{a}$ Ángeles. "La historia de la historia de la alimentación». Chronica Nova, 2009, vol. 35, pp. 105-162.

88 Abad García, Isabel y Peribáñez Otero, Jesús. «La pesca fluvial en Castilla durante la Baja Edad Media». En VAL VAldivieso, M. ${ }^{a}$ Isabel del (coord.). Vivir del agua en las ciudades medievales. Valladolid: Universidad de Valladolid, 2006, pp. 147-180.

89 Rodrigo Estevan, M. a Luz. «Fresco, frescal, salado, seco, remojado: abasto y mercado de pescado en Aragón (siglos Xiı-Xv)». En Arízaga Bolumburu, Beatriz y Solórzano Telechea, Jesús Ángel (coords.). 
bastaba para colmar las necesidades existentes en las ciudades que se veían satisfechas por el abastecimiento de lugares cercanos e incluso de lejanas costas ${ }^{90}$.

En Fuentidueńa se planteó igualmente este tipo de vigilancia exhaustiva como se puede observar en el tenor de las ordenanzas analizadas ${ }^{91}$. Por la redacción de esta norma de vigilancia se prohibía taxativamente la pesca en los ríos Duratón y Fuentes con cualquier tipo de artes, sin aportar mayores explicaciones que aclaren el motivo de cautela tan dura. El desconocimiento de la situación fluvial en aquellos años dentro de la zona de la comunidad de Villa y Tierra de Fuentidueńa, impide llegar a conclusiones prudentes. Por otro lado, además de la fuerte multa, idéntica a la que se imponía en el caso de la caza, y la retirada de los aparejos, se dejaba abierta la eventualidad de hacer una posterior investigación sobre los hechos delictivos que se llevasen a cabo contra estos ríos $^{92}$. Pero, en cualquier caso, son castigos menores comparados con los propuestos en la villa próxima de Pedraza unos años antes, que se escalonaban en tres periodos, la primera vez seiscientos maravedís, la segunda vez la misma cantidad y 20 días preso, y la tercera vez la cantidad ascendía a ochocientos maravedís y se doblaban los días que el infractor debía estar en la cárcel. Incluso aquel que incumplía, aunque no lo detuviesen en el momento, debía pagar cuatrocientos maravedís ${ }^{93}$.

La pesca y el consiguiente consumo de pescado generaron una actividad que representó un importante movimiento económico, lo que motivó una vigilancia continuada de los cauces de los ríos. Los gobiernos locales desarrollaron tanto la intervención contra las actividades ilegales pesceras, que en algunos lugares llegaron a controlar hasta las capturas que se realizaban con anzuelo que, como se puede entender, eran de mínima relevancia en el conjunto de las presas obtenidas. En Toledo se llegó a prohibir la pesca con anzuelo los domingos por la mańana antes de la hora de comer ${ }^{94}$. Indudablemente, dado el mínimo grado de agresión que sufrían los ríos por esta actuación, los acusados de estas contravenciones de la norma eran sometidos a una pena de carácter leve. Todo lo contrario de lo que sufrían aquellos que llevaban a cabo embalses y «corrales» en las pozas de los ríos para que sirviesen de criaderos de peces, impidiendo que otros pescadores se beneficiasen de la riqueza natural del río, que en dicha ciudad llegaron a ser de cinco mil maravedís, o incluso la actuación de los arrendadores que promovían la pesca ilícita en los márgenes de su arrendamiento ${ }^{95}$.

En definitiva, los pescadores que actuaban sin someterse a ninguna norma dieron mucho trabajo a los oficiales que luchaban por el cumplimiento de las medidas concejiles.

Alimentar a la ciudad en la Edad Media. Nájera. Encuentros internacionales del Medievo. Nájera: Instituto de Estudios Riojanos, 2009, pp. 547-577.

90 Guerrero Navarrete, Yolanda. «Aproximación cualitativa y cuantitativa a la dieta urbana en el siglo Xv». En Estudios de Historia Medieval. Homenaje a Luis Suárez Fernández. Valladolid: Universidad de Valladolid, 1991, pp. 245-265.

91 Ordenanzas de Fuentidueña de 1543, n. ${ }^{\circ}$ XIII.

92 Ibidem.

93 Franco Silva, Alfonso. «Pedraza de la Sierra. El proceso de formación de unas ordenanzas de villa y tierra en los siglos XIV y XV». Historia. Instituciones. Documentos, 1991, vol. 18, pp. 97-142.

94 Izquierdo Benito, Ricardo. Abastecimiento y alimentación en Toledo en el siglo XV. Cuenca: Universidad de Castilla-La Mancha, 2002, p. 83.

95 Ibidem, p. 212. 
JOSÉ MIGUEL LÓPEZ VILLALBA

ORDENANZAS SEÑORIALES Y VIDA COTIDIANA

EN EL COMIENZO DE LA EDAD MODERNA SEGOVIANA

Pero también hubieron de ocuparse de otros colectivos que realizaban actividades perjudiciales para la salud piscícola de los ríos ${ }^{96}$.

\subsection{El vino: negocio y placer}

Durante la Edad Media el cultivo de la vid fue común en las tierras limítrofes a los espacios habitados. La generalización de su cultivo en las tierras castellanas llevó aparejado un elevado consumo de un producto tan placentero, como fácil de obtener. Fueron muchos los ejemplos retóricos y literarios que cortejaron al vino a lo largo de la Edad Media, lo cual demuestra inequívocamente que su uso estaba tan extendido como normalizado ${ }^{97}$. Por parte de la Iglesia se acompañó por una nutrida literatura proveniente de los grandes conductores de la religión cristiana ${ }^{98}$. Algunos lo consideraron producto virtuoso en lo anímico y en lo medicinal, como se puede observar en los diferentes tratados de medicina de la época, en los que el vino no solo es un producto de salud sino que llega a ser recomendado para mejorar el aspecto físico ${ }^{99}$.

Las poblaciones con producción vitivinícola propia conocieron tempranamente legislaciones ad hoc para preservar las cosechas propias frente a las intrusiones del vino ajeno. Esto se logró con la continua emisión de ordenamientos locales o con la obtención de privilegios reales. Además, en algunos lugares se obligaba a los vecinos a que cultivasen la vid o ampliasen los viñedos existentes para aumentar la producción propia ${ }^{100}$. Nació de este modo una política proteccionista local, con unos resultados no siempre esperados, que dio lugar a situaciones diferentes que desfiguraron los mercados locales sin conseguir grandes avances y que en otras ocasiones provocaron largos conflictos resueltos a través de la justicia. El proteccionismo no fue un sistema económico practicado aisladamente, muy al contrario se pueden encontrar nutridos ejemplos en cualquier región de los diferentes reinos hispánicos ${ }^{101}$.

96 SÁnchez QuiÑones, Julián. «Pesca y trabajo en el reino de Toledo. La cuenca alta y media del Tajo en los siglos XII al XVI». Anuario de Estudios Medievales, 2006, vol. 36, n. ${ }^{\circ} 1$, pp. 145-169.

${ }_{7}$ Castro, Teresa de. La alimentación en las crónicas castellanas bajomedievales. Granada: Universidad de Granada, 1996; Pérez González, Maurilio. «Las bebidas alcohólicas en el medievo asturleonés a través de los textos». Estudios Humanisticos. Historia, 2008, vol. 7, pp. 61-77.

98 Entre todos los tratadistas cristianos, la excelencia nos la sugiere la figura de San Isidoro de Sevilla que a lo largo de los libros de sus Etimologías, especialmente en el capítulo 3.3-15 del libro XX, desplegó un acercamiento a diferentes campos de la alimentación, entre ellos el vino, que marcaron una forma de ver la agricultura. Isıdoro de Sevilla. Etimologías (ed. de José Oroz Reta, y Manuel A. Marcos Casquero). Madrid: Biblioteca de Autores Cristianos, 1994.

99 José Luis Martín analizó las obras de Juan Gil de Zamora en las que encontramos alusiones a las diversas virtudes del vino. Gil De Zamora, Juan. Maremagnum de escrituras, Dictaminis epithalamium, Libro de las personas ilustres, Formación del principe (traducción y estudio de José-Luis Martín). Madrid: Ayuntamiento de Zamora, 1995.

100 López Villalba, José Miguel. «El abastecimiento del vino y su política proteccionista en el alto Tajo (siglos XIV-xv)». Espacio, Tiempo y Forma. Serie III. Historia Medieval, 2011, vol. 24, pp. 143-184.

101 Ante la complejidad de reseñar una relación completa de estudios sobre el vino y el proteccionismo de su consumo en el conjunto de los reinos medievales hispanos se seńalan algunas obras destacadas por 
El vino, considerado alimento y medicina, se consumía usualmente en cualquier lugar, por lo que se organizó un sistema de abastecimiento de mayor o menor complejidad. Uno de los preceptos primordiales de dicha estructura fue conseguir que el consumo se basase, en su mayor parte, en la producción obtenida dentro de los límites de la localidad, lo cual llevó inmediatamente a consolidar una política de proteccionismo ciertamente agresivo que se extendió a lo largo de la península. No se debe olvidar que los concejos conocían las posibilidades de los circuitos comerciales al uso y su falta de capacidad para abastecer todas las necesidades alimentarias generadas en las urbes. Por lo tanto, decidieron mantener e incluso potenciar el autoabastecimiento, aunque el vino local fuese de peor calidad.

En el conocimiento de toda política de abasto de carácter proteccionista llega el momento de averiguar cómo fueron las normas que los gobiernos locales y señoriales idearon para impedir que las actuaciones no deseadas se llevasen adelante. Como es de imaginar, las dificultades impuestas incluían la superación de una serie de escalones normativos que, a modo de frenos, obstaculizaban el acceso al mercado local. La entrada de vino forastero fue siempre motivo de muchas disputas entre los propios vecinos, de estos con el gobierno concejil, entre este último y los productores que deseaban salvaguardar su negocio, y así un círculo vicioso, con su interminable colección de querellantes, en busca de una mejora en su producción, de la venta de la misma o de obtención de impuestos a costa de todo lo anterior. En pocas palabras un complejo entramado que se puede escenificar tanto en las tierras de Fuentidueńa, insertas en el valle del Duero, como en el resto de las plantaciones del reino ${ }^{102}$.

En el mercado de Fuentidueña el modelo de precios estaba en la vecina villa de Peńafiel, conocida ya en la Edad Media por la calidad de su vino, producto de la variedad de uva tinta conocida como tempranillo ${ }^{103}$. Pero las noticias se muestran contradictorias,

reinos. Para Aragón: Rodrigo Estevan, M. a Luz. "Viñedo y vino en el Somontano de Barbastro. Los siglos medievales». En Sabio Alcutén, Alberto (ed.). Vino de siglos en el Somontano de Barbastro. Una historia social y cultural: las vidas desde las viñas. Barbastro: Consejo Regulador de la Denominación de Origen Somontano, 2001, pp. 15-48; Rodrigo Estevan, M. a Luz y Sabio Alcutén, Alberto. "Cariñena. Del bino bono, colorado e de buen sabor». En Documentación sobre la viña y el vino en Cariñena, siglos XV-XVIII. Cariñena: Consejo Regulador, 1997; Rodrigo Estevan, M. ${ }^{a}$ Luz. "Claves de la expansión vitivinícola en el periodo medieval hispano: Aragón. Siglo XII-XV». Universum, Universidad de Talca, 2007, vol. 22, n. ${ }^{\circ}$ 1, pp. $72-93$. Para el reino de Valencia son de lectura obligada los análisis de PiQueras Haba, Juan. La vid y el vino en el País Valenciano (geografía económica 1564-1980). Valencia: Institución Alfonso el Magnánimo, 1981; y «La vid y el vino en Valencia: una síntesis histórica». En Maldonado, Javier y Ramos, Alberto (eds.). Actas del I Encuentro de Historiadores de la Vitivinicultura Española. El Puerto de Santa María: Ayuntamiento, 2000, pp. 285-300; asimismo se puede señalar a Ferrero Micó, Remedios. «Proteccionismo y fiscalidad municipal sobre el vino en Valencia (1515-1550)». En Estudios en recuerdo de la profesora Sylvia Romeu Alfaro. València: Universitat de València, 1989, vol. 1, pp. 345-354. Para La Rioja: Goicolea Julián, Francisco Javier. «El vino en el mundo urbano riojano a finales de la Edad Media». En la España medieval, 2007, vol. 30, pp. $217-244$. Un artículo interesante, porque relaciona los mercados de los principales reinos medievales hispanos, es el de Diago Hernando, Máximo. «El comercio de productos alimentarios entre las coronas de Castilla y Aragón en los siglos XIV y XV». Anuario de Estudios Medievales, 2001, vol. 31, n. o 2, pp. 603-648.

102 Como ejemplo de ordenamientos proteccionistas se puede acudir a los de las poblaciones situadas en los valles del río Tajo. López Villalba, «El abastecimiento del vino».

103 Ordenanzas de Fuentidueña de 1543, n. ${ }^{\circ}$ IX. 
JOSÉ MIGUEL LÓPEZ VILLALBA

ORDENANZAS SENTORIALES Y VIDA COTIDIANA

porque nos indican que a pesar de eso existía un cierto desorden en la fijación de los precios de comercialización del vino que se producía en la villa. Es posible que los vecinos productores estuviesen de acuerdo con esta desorganización por las posibilidades de maniobra que tendrían en las valoraciones de su venta. Los consumidores con toda seguridad se considerarían estafados y debido a esto se producían perturbaciones públicas. El origen de esta situación estaría en un régimen de proteccionismo señorial para el vino propio que llevó a un abuso en la cuantía de los precios impuestos al comprador por menudo. Ante las protestas de los afectados se tuvieron que tomar medidas para limitar los precios por arriba, evitando unas subidas descontroladas que perjudicaban al consumidor habitual que generalmente bebía una cantidad cercana al medio litro diario. Todo ello hizo necesaria y urgente una intervención administrativa para controlar aquellas actividades comerciales. En la ordenanza emitida por el señor se daba potestad a un regidor de la villa para que junto con un procurador fijasen dichos precios. En este caso se permitía un máximo de un maravedí más de lo que costase en la citada villa de Peńafiel. La contravención no parece estar penada con cantidad alguna, pero los encargados de establecer las valoraciones podían perder los oficios y las licencias para ejercerlos en caso de incumplir su cometido. Por debajo del coste de los caldos peñafielenses se podría manejar los precios sin límite, ajustándose a la calidad de los mismos.

Por otro lado, el señor de Fuentidueña se reserva la facultad de que sea su propia justicia la que finalmente tome cartas sobre lo que está sucediendo, con lo cual se puede conjeturar que habría ciertos sectores poco proclives a su gestión que tratarían de boicotear lo que se proponía en la ordenanza. En cualquier caso, en las villas señoriales se observa una doble vara de medir con la que los oligarcas manejan a los gobiernos concejiles. De tal suerte que en muchas ocasiones son ellos mismos los que manipulan el alza y la baja de los precios según tuviesen mayores intereses con los productores, los obligados o los regatones.

Al finalizar la cosecha, que podía dilatarse hasta el mes de octubre para conseguir los grados de maduración más elevados, se pasaba al proceso de fermentación del mosto o zumo del vino. En las ordenanzas de Fuentidueña, se contemplan las fechas extremas durante las cuales los vecinos estaban autorizados para introducir cualquier cantidad de mosto sin correctivo alguno ${ }^{104}$. El mosto se introducía sin alteración química, es decir, no se puede hablar propiamente de vino porque en esos momentos del proceso aún no se habría desatado la fermentación alcohólica. En cualquier caso, aquella situación de libertad duraba hasta San Martín de Noviembre, quedando vedado a partir de mediados de dicho mes el ingreso descontrolado de mosto. Los infractores eran castigados con sanciones de seiscientos maravedís, lo cual es indicativo de las fuertes medidas proteccionistas ya mencionadas. En otras villas cercanas la entrada de mosto se vedaba a partir de la festividad de Todos los Santos hasta la "cinquesma» como sucedía en la cercana villa de Pedraza ${ }^{105}$. Idéntica cuantía de seiscientos maravedís se asignó como castigo para aquellos que se atreviesen a meter vino sin licencia de los oficiales concejiles en la villa o en sus arrabales

104 Ordenanzas de Fuentidueña de 1543, n. ${ }^{\circ}$ XVII.

105 Franco Silva, «Pedraza de la Sierra», p. 103. 
JOSÉ MIGUEL LÓPEZ VILLALBA

ORDENANZAS SEÑORIALES Y VIDA COTIDIANA

EN EL COMIENZO DE LA EDAD MODERNA SEGOVIANA

después de que se dictase el periodo de veda. La multa, una vez cobrada, se repartía según el criterio medieval de hacer una tripartición de la misma: una parte para la cámara del concejo, otra para el denunciante y la última para el juez municipal que lo juzgase ${ }^{106}$.

La veda, como prohibición temporal, fue el comienzo invariable en la lucha contra los infractores de la introducción de vino, uva o mosto fuera de los tiempos y espacios permitidos. Indudablemente les debía resultar muy beneficioso seguir introduciendo vino prohibido a pesar de las sanciones. Es evidente que el contrabando debía funcionar con regularidad y obtenían de todo aquel montaje ilegal unos beneficios generosos en casi todas las ciudades y villas de Castilla. Por ello, se dictaron órdenes a lo largo de todo el reino por medio de las cuales se diputaba a ciertos oficiales para que hiciesen pesquisas que pudiesen desentrañar quién introducía vino, uva o mosto indebidamente.

Otra de las actividades de vigilancia que se llevaban a cabo en Fuentidueńa pasaba por el control de los módulos de venta al público del vino que se encontraban sin normalización aparente. La normativa aplicada prohibía que se hiciese por medias azumbres ni por azumbres, medidas de capacidad de uno y dos litros, respectivamente. Con ello se buscaba regularizar los susodichos patrones de las medidas, ya que al venderse el producto en diferentes lugares del señorío, la confusión sería elevada ${ }^{107}$.

Igualmente se perseguía a los que traspasasen el vino sin haber sido señalado un precio por los encargados del concejo. En el caso de que los bodegueros lo hiciesen así se exponían a que todo el vino que tenían almacenado para la venta quedase estancado. Una pena muy grave, ya que por medio del estanco se prohibía el curso libre de un producto que de este modo pasaba a una especie de monopolio, en este caso ejercido por el concejo, para la venta del mismo. En otras ocasiones se otorgaba la capacidad del estanco a algunos particulares que lo obtenían a través de un pago adelantado. Al quedar retenido el género, el concejo de Fuentidueña gestionaba la comercialización y solo podía ser transferido en grandes cantidades, quedando vetada la venta por menudeo ${ }^{108}$. Dicha comercialización interesaba al vendedor porque alcanzaba a mejorar el beneficio por manejar cantidades más elevadas en el precio minorista. Siempre se dejaba la puerta abierta para administrar la venta de otra forma, aunque se requiriese un permiso del concejo. Este se concedía por medio de una licencia de los regidores o de la justicia. Si no había autorización y se obraba sin tal permiso, las penas asignadas a estas contravenciones eran de trescientos maravedís en cada una de ellas, repartidos según la costumbre ${ }^{109}$.

\section{Conclusión}

A modo de conclusión se puede resumir que nos encontramos ante unas ordenanzas concejiles de semblante medieval, aunque dictadas en la primera mitad del siglo XvI.

106 Ordenanzas de Fuentidueña de 1543, n. $^{\circ}$ XVII.

107 Ibidem, n. ${ }^{\circ}$ XVIII.

108 En cualquier caso siempre buscaban artimańas para seguir vendiendo el producto y saltarse la norma, como puede verse en nuestro análisis: «El abastecimiento del vino», pp. 163-165.

109 Ordenanzas de Fuentidueña de 1543, n. ${ }^{\circ}$ XVII. 
JOSÉ MIGUEL LÓPEZ VILLALBA

ORDENANZAS SEÑORIALES Y VIDA COTIDIANA

No existió una cisura temporal en la redacción de normas concejiles que delimitaban los asuntos comerciales, políticos, sociales o simplemente de la vida cotidiana llevada a cabo entre los habitantes de las poblaciones. Muchas de estas pautas de comportamiento están llenas de inercias del pasado y hemos de comprobar la data de emisión para observar que están redactadas fuera de los límites temporales de la Baja Edad Media. Los aspectos estudiados se encuadran en los espacios de convivencia laboral o festiva desarrollados en las urbes; es aquí donde mejor se observa la escasa evolución de la norma que generalmente aparece como compilación de lo anteriormente dispuesto y no como renovación novedosa de la misma.

Las leyes analizadas son unas ordenanzas interventoras que indudablemente encubren unos fines fiscalizadores de aspectos aparentemente inocentes de la vida cotidiana. No obstante, comparadas con otras coetáneas resultan bastante livianas, puesto que se acompañan de muchas puertas abiertas por las que salir de la pauta establecida. Tal vez, la relajación en algunos capítulos esté motivada por las complicaciones y los pleitos consiguientes que mantuvo el anterior señor de la villa.

Las ordenanzas de Fuentidueña ofrecen un mejor conocimiento de las actividades festivas junto con las prohibiciones que generalmente acompańaban su discurrir a comienzos del mundo moderno. Un discernimiento que nos ayudará, junto con otros estudios, a mejorar la visión de la fiesta religiosa y de la obligación del precepto de asistencia a la misma, de la celebración de las ceremonias nupciales, de la práctica de la caza y de la pesca como medios de subsistencia y las persecuciones que sufrían los pecheros todavía en los años centrales del siglo Xvi. Finalmente nos hablan del vino y de los muchos problemas que se suscitaron a lo largo de todo el territorio hispano, motivados por las políticas proteccionistas que sobre dicho producto practicaron los concejos ${ }^{110}$.

La fiesta servía como medida del tiempo, marcando significativamente el calendario laboral debido al elevado número de las mismas a lo largo del año ${ }^{111}$. El origen de las múltiples manifestaciones festivas era tan diverso como singular, por ello se puede concluir que en muchas localidades castellanas bajomedievales alcanzaban el centenar de días festivos, aunque en puridad, no pasarían de las tres decenas a lo largo del año natural ${ }^{12}$. Para hacer un cómputo general de festividades se pueden ignorar aquellas de escasa trascendencia social, es decir, las dedicadas a los santos no patronos de las localidades, aquellas otras que encuentran su origen en las cofradías o, incluso, las que teniendo un marcado carácter político restringían el número de los destinatarios.

El domingo fue fiesta devota obligada, puesto que por prescripción normativa había que olvidar la práctica de actividades serviles. El fervor desarrollado a lo largo de los siglos medievales en el agro castellano resultó muy favorable a la creencia desaforada, a la superstición y a la milagrería. A pesar de ello, los domingos, día santo de la Cristiandad,

110 Ruiz Domenec, José Enrique. "Reflexiones sobre la fiesta en la Edad Media». En NúÑEz Rodríguez, Manuel (coord.). El rostro y el discurso de la fiesta. Santiago de Compostela: Universidade de Santiago de Compostela, 1994, pp. 31-43.

111 Ladero Quesada, Las fiestas en la cultura medieval, p. 30.

112 Asenjo González, María. «Fiestas y celebraciones en las ciudades castellanas en la Baja Edad Media». Edad Media. Revista de Historia, 2013, vol. 14, pp. 35-61. 
no fueron siempre respetados al completo, como podemos observar por las ordenanzas analizadas y las penas impuestas por el incumplimiento de las mismas. Detrás de la desobediencia no estaba la inobservancia del culto por cuestiones devotas, sino para poder llevar a cabo sus actividades de mantenimiento, por muy serviles que estas se presentaran ante los grupos más privilegiados. Si se observa el comportamiento de la sociedad rural en su menester cotidiano, se entiende que el trabajo no era cuestión de dignificación personal sino de mera supervivencia. En última instancia, todo ello propició que, ante casos muy específicos, algunas diócesis permitieran que los días de fiesta de guardar se llevasen a cabo algunas labores serviles.

Junto a las fiestas propias de cada lugar, ordinariamente de tipo devoto, siempre había unos días para celebrar algunos festejos civiles de modo ocasional, producidos por acontecimientos singulares. Entre las causas más frecuentes que podían presentarse estarían: la llegada de los reyes u otros personajes importantes a la población; la celebración de acontecimientos sonados, como el nacimiento de herederos al trono e incluso la toma de importantes ciudades musulmanas. Incluidas en este grupo estarían las festividades propiciadas por los enlaces matrimoniales, que en algunas ocasiones duraban varios días ${ }^{113}$. Estos excesos acabaron prohibidos fuera del estrato nobiliario, en aras de la clara distinción de grupos sociales. Igualmente estuvieron vedados, desde fechas muy cercanas, los juegos, porque ordinariamente implicaban apuestas de dinero y por lo tanto problemas graves para los participantes en las partidas de cartas o las tiradas de dados ${ }^{114}$.

El vino fue considerado como un alimento esencial y su uso se popularizó, de modo que las urbes decidieron defender sus cosechas vitivinícolas frente a la producción ajena. Dictaron normas, acudieron al señor e incluso al rey para conseguir prerrogativas que ayudasen a proteger unas cosechas que proporcionaban un vino poco apetecible a los paladares más exquisitos, pero que ayudaba a mantener la economía propia. Entre las dificultades que presentaba el sistema proteccionista se encontraban las complicaciones para la fijación de los precios. La legislación concejil estuvo respaldada por las elites urbanas que castigaron todo lo proveniente de los extramuros geográficos, mientras favorecían a los propietarios locales en muchos casos pertenecientes a su red clientelar.

Sin alcanzar la complejidad del municipio de la plena Edad Moderna, la normalización de los diferentes ámbitos fue creciendo al compás del aumento de su capacidad de gestión. El control de la economía del mercado sirve, entre otras muchas actividades, de soporte para todo tipo de actuaciones municipales que necesitan de unos fondos adecuados para emprenderlas. El concejo ha de propiciar un cierto equilibrio de mercado entre vendedores y compradores locales que solo se podría sustentar incentivando la producción propia, por un lado, y, por otro, controlando a los que trastornen este sistema. Por ello las medidas de salvaguardia de los productos internos deben pasar por la vigilancia extrema de los externos. Quizá, la solución solo la encontraron amenazando a todos aquellos que podían irrumpir en el proceso, tal como se ve en los patrones estudiados.

113 Sobre esta cuestión un trabajo que no ha perdido su vigencia: Martínez CarRILLo, «Elitismo y participación popular».

114 Mantel, María Marcela. «Carácter socioeconómico de los juegos y entretenimientos en Castilla. Siglos XIII al XV». Estudios de Historia de España, 1990, vol. III, pp. 51-116. 
JOSÉ MIGUEL LÓPEZ VILLALBA

ORDENANZAS SEÑORIALES Y VIDA COTIDIANA

EN EL COMIENZO DE LA EDAD MODERNA SEGOVIANA

En definitiva, las normas aplicadas fueron tan numerosas que se puede aseverar la existencia de una suerte de espacio en que el poder local, en este caso controlado por el señor, se movía sin interferencias externas. La rigurosidad que se aplica actualmente en el entendimiento de la ley, con las consabidas excepciones, quedaba diluido por la generosidad con que se otorgaban las mismas ${ }^{115}$. La ausencia de normativa común para solucionar estos y otros inconvenientes propició el otorgamiento de disposiciones particulares. Las normas se acumularon y cada población se vio abocada a la vigilancia individualizada del hecho, lo cual no impidió que igualmente no fueran respetadas al completo.

\section{ApÉNDICE DOCUMENTAL}

\section{3, septiembre, 7. FUENTIDUEÑA (SEGOVIA).}

Copia simple de las ordenanzas de la Comunidad de Villa y Tierra de Fuentidueña aprobadas por don Álvaro de Luna y Manrique, IV señor de Fuentidueña.

A.- Archivo Diocesano de Segovia.- Histórico-571410. Papel. 7 hojas. Buena conservación ${ }^{116}$.

Este es un traslado bien e fielmente sacado de unas hordenanças que el muy illustrísimo señor don Álvaro de Luna, my señor, hizo y hordenó, su thenor de las quales es este que se sigue:

I. Otrosý, porque a cavsa de no se castigar los que injustamente entran tierras escaradas se syguen muchos pleitos e diferençias por manera que, como saben que no les llevan pena por las entrar, cada uno se atreve a entrar las dichas tierras injustamente e hazer mal a sus beçinos, de lo qual resulta gran dańo, espeçialmente que my justiçia e rregidores el día de ayuntamiento casi non se ocupan sino en prober lo susodicho, e por lo hebitar e por que mis vasallos non se atreban a fazer mal unos a otros, e injustamente tomarse las tierras escaradas, hordeno y mando que ninguna persona sea osada de entrar a otro vezino nynguna tierra escarada, que pague el que asý la entrare doçientos marabedís, la terçia parte para el dueńo, o la persona que lo denunçiare, e otra terçia parte para la justiçia e la otra parte para los gastos del ayuntamiento.

II. Yten que a cavsa de ararse las tierras escaradas y de herencia que confinan las unas con las otras a un surco, los señores de las tierras de herencia osurpan e toman para las tierras escaradas que con ellos asurcan e desto viene mucho perjuyçio e daño a la dicha mi villa e su tierra. Por hende por hebitar lo suso dicho hordeno y mando que ninguna persona sea osada de arar las tales tierras escaradas que confinaren con las de herencia o las de herencia con las descarado a un surco, so pena de seysçientos maravedís, la terçia parte para la cámara e la otra terçia parte para la parte que lo denunçiare e la otra terçia parte para la justicia, e sobre ello se pueda hazer pesquisa por toda la tierra.

III. Otrosý, ordeno y mando que ningún domingo ni día de Nuestra Señora, ny fiesta del apóstol, nin de las otras que la Santa Madre Yglesia manda guardar, juegen ninguna manera de

115 Franco Silva, Alfonso. Estudios sobre ordenanzas municipales (siglos XIV-XV). Cádiz: Universidad de Cádiz, 1998.

116 En la primera página del cuadernillo y escrito en letra posterior y en diferentes apuntes, algunos claramente errados: «Legajo 2, señorío»; «Lagunillas n. ${ }^{\circ}$ 12»; «Partido de Fuentidueńa, ańo 1443». «Mandamiento dado por el señor obispo de Segovia don Juan de Arias y ordenanzas que hizo don Álbaro de Luna, señor de Fuentidueńa, sobre la caza y pesca y las fuertas». "Es solo un trasumpto simple de algunas de las ordenanzas del illustrísimo don Álvaro de Luna, al parecer sobre lo que se expresa». Tachado: «n. ${ }^{4}$ » $\mathrm{y}$ «n. ${ }^{\circ}$ 5». 
juego antes de misa mayor, so pena de treçientos maravedís. Los çiento para la yglesia donde el tal que jugare fue perrochiano, e los otros doçientos maravedís para el acusador e justiçia que los sentençiare.

IV. Yten que en los tales dias de suso dichos nadie sea hosado de huñir carreta, nin hazer otras obras serviles hasta ser salidos de las vísperas so la dicha pena. Salvo sy non fuere con cavsa neçesaria.

V. Otrosý so la dicha pena mando que ninguno caçe nin pesque en los dichos días antes de misa, agora sea a las partes que están bedadas e a lo desbedado. E, sy fuere a lo vedado, pague la pena de los seysçientos maravedís de la caça y pesca rrepartidos conforme a la hordenança que sobre ello habla; y, si fuere a lo desvedado, pague la dicha pena de los dichos seysçientos marabedís.

VI. Otrosý que ninguna persona sea osado de yr camino en ninguno de los dichos días antes de misa mayor so pena de doçientos maravedís, la terçia parte para la fábrica de la yglesia donde fueren perrochano e las otras dos terçias partes para el denunçiador e juez que lo sentençiare.

VII. Yten que ninguno sea osado de jugar nynguna manera de juego en las tabernas desta mi villa e su tierra, que de jugar se sigue muchos daños e inconbientetes (sic) y enojos, muertes y heridas, en nyngund día que sea, so pena de trescientos marabedís, los çiento para la cámara y los otros doçientos para el acusador que lo acusare e juez que lo sentençiare.

VIII. Yten que a cualquier pastor que con sus ganados andubiere a sabiendas en panes o en vińas, huertas o alemedas (sic) o rrubiales pague de pena çien maravedís, la terçia parte para la guarda e la terçia parte para el conçejo e otra terçia parte para el juez que lo sentençiare, e más çien maravedís al dueño de la tal heredad e más el apreçio. Y el dueño o guarda que lo denunçiaron sea creído por su juramento; e, sy otra persona alguna lo denunçiare, que lo pruebe e aya la terçia parte de la pena de suso contenida. E, sy no paresçiere que andava a sabiendas el dicho pastor con el dicho ganado, se le llebe la mitad de la pena sobredicha.

IX. Otrosý mando que, sy algún pastor por su negligençia fuere tomado en ocho bezes façiendo daño, que pague la dicha pena doblada.

$\mathrm{X}$. Yten que a cavsa de non aber horden en el poner del vino que en esta villa se coge se an seguido e syguen muchos ynconbenientes y enojos y escándalos de los veçinos della, se obiere de vender lo ponga un rregidor e un procurador desta mi villa a segund les paresçiere e vieren que mereçe el dicho vino, con tanto que non puedan ponerlo a más preçio de un maravedí más en cada açunbre que valiere en Peńafiel y dende puedan bajar avida consyderaçión a la calidad del vino lo que les paresçiere. E, sy lo contrario hiçieren, por el mysmo hecho ayan perdido los ofiçios; y, si no hiçieren en $\mathrm{el}^{117}$ poner lo que son obligados, mando a mi justiçia que lo bean e pobrean en ello.

XI. Yten que en lo de las huertas se guarde la hordenança antigua con tanto que qualquier ganado mayor o menor que se hechare de noche syn guarda, estando cercadas las dichas huertas, pague el apreçio y pena de la dicha hordenança.

XII. Otrosý que qualquier rres mayor que hiçiere daño en los árboles de la vega o en otras partes pague beynte y çinco marabedís de día e çinquenta de noche, e más el apreçio.

XIII. Yten que ninguno pesque en rrío Fuentes ny en Duratón, con nynguna manera de pescar, so pena de seysçientos marabedís, la terçia parte para la cámara, //2r las otras dos terçias partes para el denunçiador e para la justiçia que lo sentençiare; e más los armadixos perdidos e que sobre ello se pueda hazer pesquisa.

XIV. Yten que el que matare liebre o conexo o perdiz en tienpo de fortuna que se guarde la ley del reyno.

$\mathrm{XV}$. Yten que qualquier que non çercare su huerta dentro del término que le fuere mandado por my justiçia e rregidores, que no lleve la pena, más del apreçio solamente.

117 A continuación y tachado: «ofiçio». 
JOSÉ MIGUEL LÓPEZ VILLALBA

ORDENANZAS SEÑORIALES Y VIDA COTIDIANA

EN EL COMIENZO DE LA EDAD MODERNA SEGOVIANA

XVI. Yten que qualquier que catare o deçerrajare cañal por la primera bez pague seysçientos marabedís, e por la segunda la pena doblada, e por la terçera vez sea traýdo a la bergüença, e todavía pague la dicha pena doblada. Y en quanto a las penas pecuniarias sea creýdo la guada (sic) o el dueño del tal cañal otra qualquier persona que le tomare o biere catando el tal cañal, syendo beçino o fijo de veçino desta mi villa e su tierra de diez ocho años arriba. Y lo mismo se entienda en el que catare çestones, la qual dicha pena se rreparta por terçios, conforme a la hordenança de la pesca.

XVII. Yten que hasta el día de San Martín de Nobienbre todos los veçinos d'esta villa puedan meter el mosto que quisieran. E dende en adelante el que lo metiere aya perdido el tal mosto e más pague de pena seysçientos maravedís, la terçia parte para la cámara e las otras dos terçias partes para el que lo acusare e juez que lo sentençiare. E so la dicha pena nadie pueda meter en esta dicha villa e sus arrabales vino syn liçençia de justiçia e rregidores después de hechar la vieda.

XVIII. Otrosý, sy algún vino estoviere puesto e se vendiere que esta villa, non sea hosada otra persona ninguna vender por açunbres ni medios açunbres, so pena de treçientos maravedís rrepartidos en esta manera, la terçia parte para el conçejo desta villa e las otras dos terçias partes para el denunçiador e juez que lo sentençiare. E so la dicha pena nynguno sea osado de vender su vino syn que se lo pongan; e, sy se lo pusieren e non lo quisiere bender al preçio, que sea por estancado e non lo puedan vender por menudo, so la dicha pena, syn liçençia de justiçia e rregidores.

XIX. Yten que nyngund veçino desta villa o su tierra tenga pastor de catorçe ańos abaxo; e, sy lo tobiere, el tal pastor non pueda salvar su ganado, syno que el dueńo del tal ganado pague el daño, sy él no lo salvare.

XX. Yten, por que mejor los panes y biñas, huertas e pobedas y las otras semillas sean guardadas en esta villa e su tierra, mando que cada lugar en su conçejo tome guarda de confiança, so pena que, sy paresçiere e se abiriguare el no ser tal la dicha guarda, que el dicho conçejo sea obligado a pagar todos los daños e apreçios que se hiçieren, e más seysçientos maravedís de pena, la terçia parte para las obras públicas desta villa e su tierra e la otra terçia parte para el juez que lo sentençiare.

XXI. Yten que, por cabsa de no se aber guardado ny conservado los montes d'esta mi villa e su tierra, se a seguido muy gran daño y perjuiçio, ansý para los abrigos de los ganados como la carestía de la leña que hay en esta mi billa e su tierra. Por ende hordeno y mando que ninguno corte pies de rroble nin ençina en el Robleçillo, ny Ençinar, ny monte de los Valles, ny matas de Fuente el Olmo y ençinas de Santa Luçía, ny en los montes encomendados en la tyerra, so pena de seysçientos maravedís rrepartidos en esta manera, la terçia parte para la cámara e otra terçia parte para el denunçiador e terçia parte para la justiçia que lo sentençiare; e a la rrama sesenta marabedís rrepartidos segund dicho es.

XXII. Yten, porque soy informado que en las bodas que se hazen en esta my villa e su tierra, de allegar muchas gentes a ellas, se syguen rruydos y escándalos y heridas e muertes de honbres y allende desto se hazen eçesivos gastos en las comidas que se dan en las dichas bodas, de lo qual los dichos mis vasallos rreçiben gran daño e perjuyzio, por ende hordeno y mando que, por hibitar los dichos delitos y heçesibos gastos, que agora nin de aquí adelante nynguno sea osado a ningunas bodas que se hizieren de dar de comer más de una comida; e a ella pueda conbidar todas las personas que quisieren; e que a la çena ny a otro día no estén más de los parientes que bibieren en el dicho lugar, conbidándolos el que ansý se casare o el padre del nobio o otra persona que obiere de convidar, so pena de seysçientos maravedís, la terçia parte para la fábrica del tal lugar e las otras dos terçias partes para la cámara e justiçia e acusador. E qualquier que se quedare a çenar fuera de los susodichos pague de pena doçientos marabedís pagados en la forma susodicha. 
XXIII. Otrosý, por quanto soy hynformado que sobre el dar de la plata está hecha una ordenança antigua, la qual no se guarda como debe, por tanto, por la hutilidad e provecho que della se sigue, mando que se guarde en todo y por todo como en ella se contiene, ansý en lo de la (sic) como en lo de los vestidos, e más doçientos maravedís por cada vez que se hallare que traen más de conforme a la dicha hordenança, la terçia parte para la cámara e la terçia parte para la justiçia e la terçia parte para el que lo acusare.

XXIV. Otrosý, por quanto de senbrar mucha rrubia se enbaraçan las mejores tierras que son para llevar pan e non se coge pan, por ende hordeno y mando que nyngund veçino d'esta villa e su tierra nin de otra parte pueda senbrar rrubia en el término d'ella, sy no fuere senbrando con cada hanega de grana dos hanegas de pan; e de otra manera no lo pueda senbrar y, si lo senbrare, cayga en pena de seysçientos maravedís por cada hanega que senbrare, rrepartidos la terçia parte para la cámara e otra terçia parte para la persona que lo denunçiare; e que sobre ello se pueda fazer pesquisa.

Don Álvaro de Luna.

Ansý fechas e publicadas las dichas hordenanças e formadas de su merçed, como de suso va dicho e declarado, su merçed dixo que mandava e mandó a mí, Luis de Mercado, escrivano público en la dicha villa de Fuentedueña, las haga apregonar públicamente en las plaças e mercados d'esta dicha villa de Fuentedueńa, por que venga a notiçia de todos e nadie pueda en ellas pretender ynorançia.

Testigos, Christóval Marroquí, veçino de Fuente el Olmo, e Alonso de Carvallido, veçino de la dicha villa.

En la villa de Fuentedueńa, a syete días del mes de setienbre, año del nasçimiento de nuestro Salvador Ihesu Christo de mill e quinientos e quarenta y tres años. En presençia de mí, Luis de Mercado, escrivano público en la dicha ${ }^{118}$ villa e su tierra, por boz de Martín Alonso, pregonero público, se pregonaron estas hordenanças altas boçes ynteligibles de verbo ad verbo, como en ellas y en cada una dellas se contiene, estando presentes muchas e asaz personas de la dicha villa e su tierra. E después de las aber apregonado, el dicho pregonero dixo de se apregonar públicamente, por que venga a notiçia de todos e porque ninguno pretenda ynorançia.

En fee de lo qual, lo firmé de mi nonbre.

Mercado $^{119}$.

118 El escribano repitió: «en la dicha».

119 En la última hoja de papel y escrito en letra muy posterior: «Son de caza e pesca en Lagunillas». 